\title{
Subduction Factory 5: Unusually low Poisson's ratios in subduction zones from elastic anisotropy of peridotite
}

\author{
Bradley R. Hacker ${ }^{1}$ and Geoffrey A. Abers ${ }^{2}$ \\ Received 26 January 2012; revised 30 April 2012; accepted 2 May 2012; published 15 June 2012.
}

[1] The growing capability to measure seismic velocities in subduction zones has led to an unusual observation: $\mathrm{V}_{\mathrm{P}} / \mathrm{V}_{\mathrm{S}}$ ratios as low as 1.65 with $\mathrm{V}_{\mathrm{S}} \sim 4.7 \mathrm{~km} / \mathrm{s}$ in the mantle wedge of some subduction zones. This is difficult to explain because most minerals have $\mathrm{V}_{\mathrm{P}} / \mathrm{V}_{\mathrm{S}}$ ratios $>1.75$, and some of the likely alteration phases in mantle rocks, like antigorite, phlogopite, clinohumite and chlorite have isotropic high $\mathrm{V}_{\mathrm{P}} / \mathrm{V}_{\mathrm{S}}$ ratios. It is possible that these measurements are biased by anisotropy in rock fabric or by the raypaths through these regions, leading to relatively high $\mathrm{V}_{\mathrm{S}}$ estimates and/or relatively low $\mathrm{V}_{\mathrm{P}}$ estimates compared with isotropic averages. Strong anisotropy has been documented in several mantle wedges, but its effect on velocity estimates are typically ignored. Anisotropic peridotites may produce the observed $\mathrm{V}_{\mathrm{P}} / \mathrm{V}_{\mathrm{S}}$ ratios if olivine [100] axes are perpendicular rather than parallel to raypaths, consistent with typical seismic sampling geometries and with fabric predictions for wedge corner flow. Hence, low $V_{P} / V_{S}$ ratios may be an indicator of strong anisotropy, rather than unusual composition, and may provide a useful additional constraint on orientation and strength of the rock fabric.

Citation: Hacker, B. R., and G. A. Abers (2012), Subduction Factory 5: Unusually low Poisson's ratios in subduction zones from elastic anisotropy of peridotite, J. Geophys. Res., 117, B06308, doi:10.1029/2012JB009187.

\section{Introduction}

[2] Recent improvements in the ability to resolve seismic velocities in subduction zones have led to the discovery of anomalously low $\mathrm{V}_{\mathrm{P}} / \mathrm{V}_{\mathrm{S}}$ (equivalent to low Poisson's ratio, and used here interchangeably) domains within several subduction-zone mantle wedges (Figure 1 and pink boxes in Figure 2). Specifically, the $\mathrm{V}_{\mathrm{P}} / \mathrm{V}_{\mathrm{S}}$ ratio for a subduction mantle wedge is typically 1.76-1.82 [Zhang et al., 2004; Syracuse et al., 2008; Tsuji et al., 2008], and yet $\mathrm{V}_{\mathrm{P}} / \mathrm{V}_{\mathrm{S}}$ as low as $1.65-1.72$ has been reported for depths of 70 $100 \mathrm{~km}$ above the flat-slab portion of the Nazca plate at $31^{\circ} \mathrm{S}$ [Wagner et al., 2005, 2006, 2008], and $\mathrm{V}_{\mathrm{P}} / \mathrm{V}_{\mathrm{S}}$ as low as $1.65 \pm 0.03$ [Rossi et al., 2006] or 1.68-1.72 [EberhartPhillips et al., 2006] has been reported for depths of 60-90 km above the eastern end of the Alaskan slab. Similarly low $\mathrm{V}_{\mathrm{P}} / \mathrm{V}_{\mathrm{S}}$ has been suggested for the Kurile backarc, using a method with less spatial resolution [Zheng and Lay, 2006]. The $\mathrm{V}_{\mathrm{S}}$ for these observations is in the range of 4.7-4.8 km/s [Wagner et al., 2005; Wagner et al., 2006, 2008], and 4.6-4.8 km/s [Eberhart-Phillips et al., 2006].

\footnotetext{
${ }^{1}$ Earth Science, University of California, Santa Barbara, California, USA.

${ }^{2}$ Lamont-Doherty Earth Observatory, Earth Institute at Columbia University, Palisades, New York, USA.

Corresponding author: B. R. Hacker, Earth Science, University of California, Santa Barbara, CA 93106-9630, USA. (hacker@geol.ucsb.edu)

(C)2012. American Geophysical Union. All Rights Reserved.
}

The wavelengths of the seismic waves imply that such low$\mathrm{V}_{\mathrm{P}} / \mathrm{V}_{\mathrm{S}}$ features are $\sim 10-30 \mathrm{~km}$ in their minimum dimension, at least in Alaska and the Andes where the features are defined by tomography. Also, localized patches with low$\mathrm{V}_{\mathrm{P}} / \mathrm{V}_{\mathrm{S}}$ may be present elsewhere in the back-arc wedge [e.g., Zhao et al., 2009]. Thermal models imply that the temperatures at these depths are $600-900^{\circ} \mathrm{C}$ for Chile [Gutscher et al., 2000] and $900-1200^{\circ} \mathrm{C}$ for Alaska [Abers et al., 2006], although the flow geometry above these shallowdipping slabs remains uncertain.

[3] Such low $V_{P} / V_{S}$ ratios are puzzling because the dominant upper-mantle mineral olivine has isotropic $\mathrm{V}_{\mathrm{P}} / \mathrm{V}_{\mathrm{S}}$ ratios of 1.76-1.78 [Hacker and Abers, 2004] at $600-1400^{\circ} \mathrm{C}$ and 2-3 GPa. These observed ratios are also significantly lower than the global Earth average; for example, the reference model ak135 [Kennett et al., 1995] has a $\mathrm{V}_{\mathrm{P}} / \mathrm{V}_{\mathrm{S}}$ ratio of 1.79 at $70-120 \mathrm{~km}$ depth. What plausible explanation is there then for the $\mathrm{V}_{\mathrm{P}} / \mathrm{V}_{\mathrm{S}}$ ratios that are so much lower? Both quartz [Eberhart-Phillips et al., 2006; Rossi et al., 2006; Zheng and Lay, 2006] and enstatite [Wagner et al., 2008] have been suggested as the cause.

[4] This paper explores alternatives to explain the very low $\mathrm{V}_{\mathrm{P}} / \mathrm{V}_{\mathrm{S}}$ ratios of $\sim 1.65$ observed in several mantle wedges. We conclude that low $V_{\mathrm{P}} / \mathrm{V}_{\mathrm{S}}$ ratios in subduction zone mantle wedges can be explained by the velocity anisotropy of peridotite with oriented minerals.

\section{Isotropic Velocities}

[5] If the mantle wedge is composed of unmetasomatized MORB-depleted mantle (DMM) or pyrolite, the constituent minerals at $800-1450^{\circ} \mathrm{C}$ and $2-3 \mathrm{GPa}$ should be $57-60 \%$ 


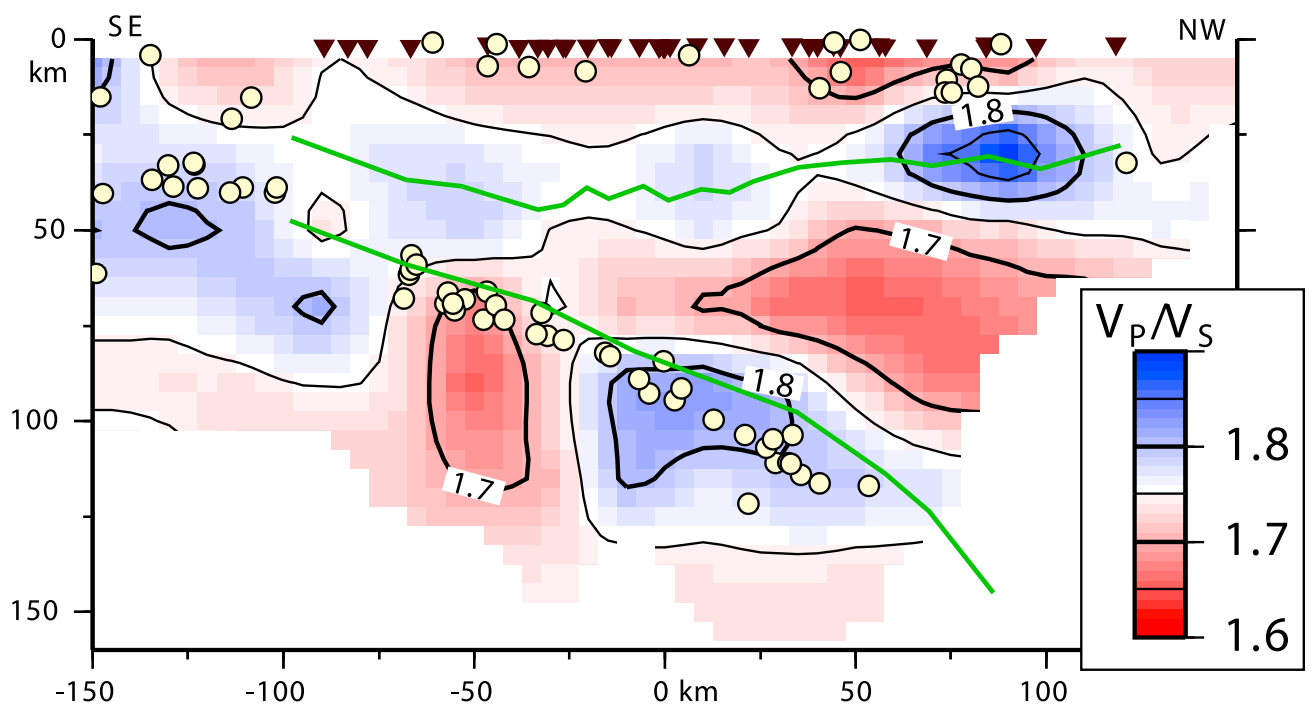

Figure 1. Low $\mathrm{V}_{\mathrm{P}} / \mathrm{V}_{\mathrm{S}}$ ratios in mantle wedge beneath central Alaska. From traveltime inversion of local data [after Rossi et al., 2006]. Region in mantle wedge of $\mathrm{V}_{\mathrm{P}} / \mathrm{V}_{\mathrm{S}}<1.65$ is also seen in receiver functions, which recover values as low as 1.60. Green lines are probable limits of wedge mantle based on modeconverted signals in the coda of teleseismic waves; circles are earthquakes; triangles are stations.

olivine, $16-27 \%$ orthopyroxene, $11-14 \%$ clinopyroxene, and $9-12 \%$ garnet with $\mathrm{Mg} \# \mathrm{~s}(\mathrm{Mg} /(\mathrm{Mg}+\mathrm{Fe}))$ of $89-90$, 91-92, 93-96, and 75 respectively (modes and compositions calculated using Perple X 7 [Connolly and Petrini, 2002] and the 2004 Holland and Powell [1998] database). Are the calculated velocities of such mixtures at elevated $\mathrm{P}$ and $\mathrm{T}$ compatible with the velocities observed in mantle wedges?

\subsection{Elasticity Tensor}

[6] Because of symmetry considerations, the fourth-rank elasticity tensor can be described by a $6 \times 6$ stiffness matrix

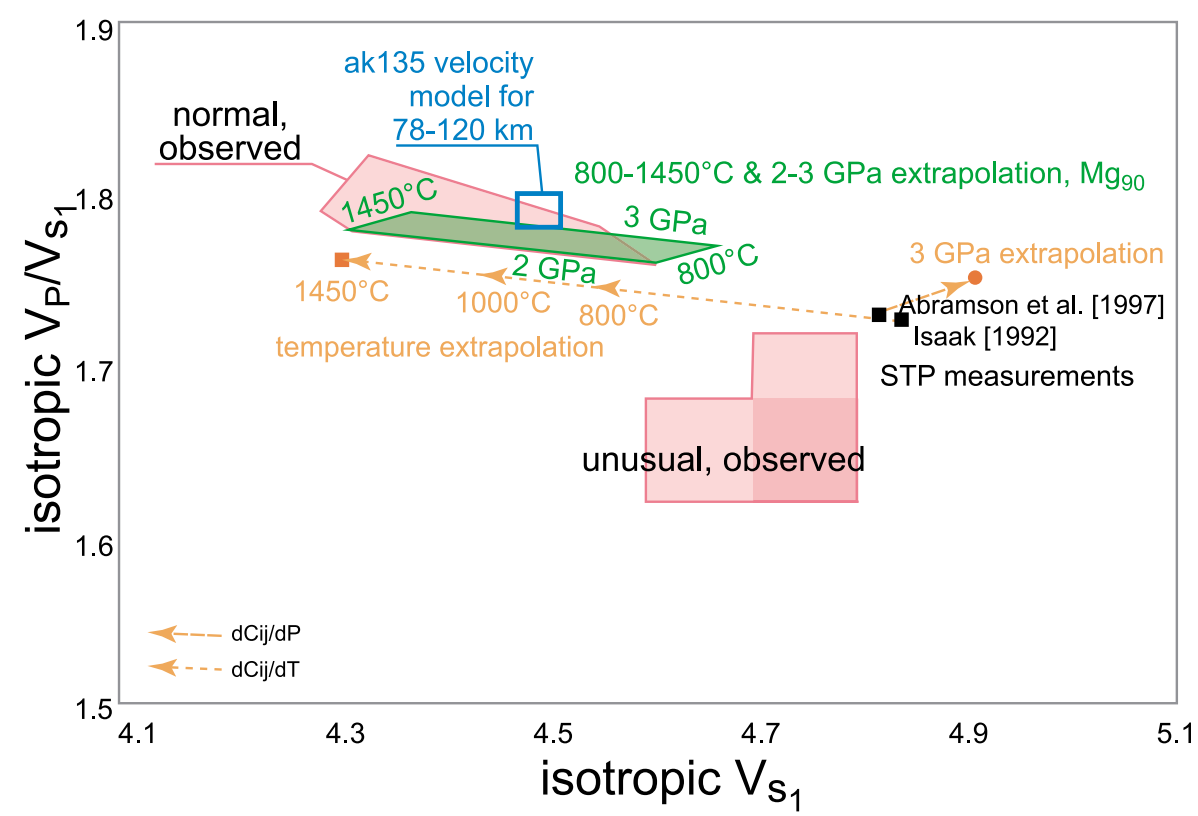

Figure 2. Olivine isotropic velocities. $S$-wave speeds and $V_{\mathrm{P}} / \mathrm{V}_{\mathrm{S}}$ ratios observed in some subduction zones (pink rectangles) are unusual with respect to the ak135 velocity model [Kennett et al., 1995] and to 'normal' observations in subduction zones (Nicaragua mantle wedge data of Syracuse et al. [2008]). They are also unusual with respect to isotropic velocities of olivine single crystals i) measured at STP (black squares); ii) extrapolated to $600-1200^{\circ} \mathrm{C}$ (orange) [Isaak, 1992]; iii) olivine isotropic velocities extrapolated to $3 \mathrm{GPa}$ (orange) [Abramson et al., 1997]; or iv) olivine isotropic velocities extrapolated to $600-1200^{\circ} \mathrm{C}$ and 2-3 GPa (green) (using the method of Hacker and Abers [2004] with the data of Isaak [1992] and Abramson et al. [1997]). 


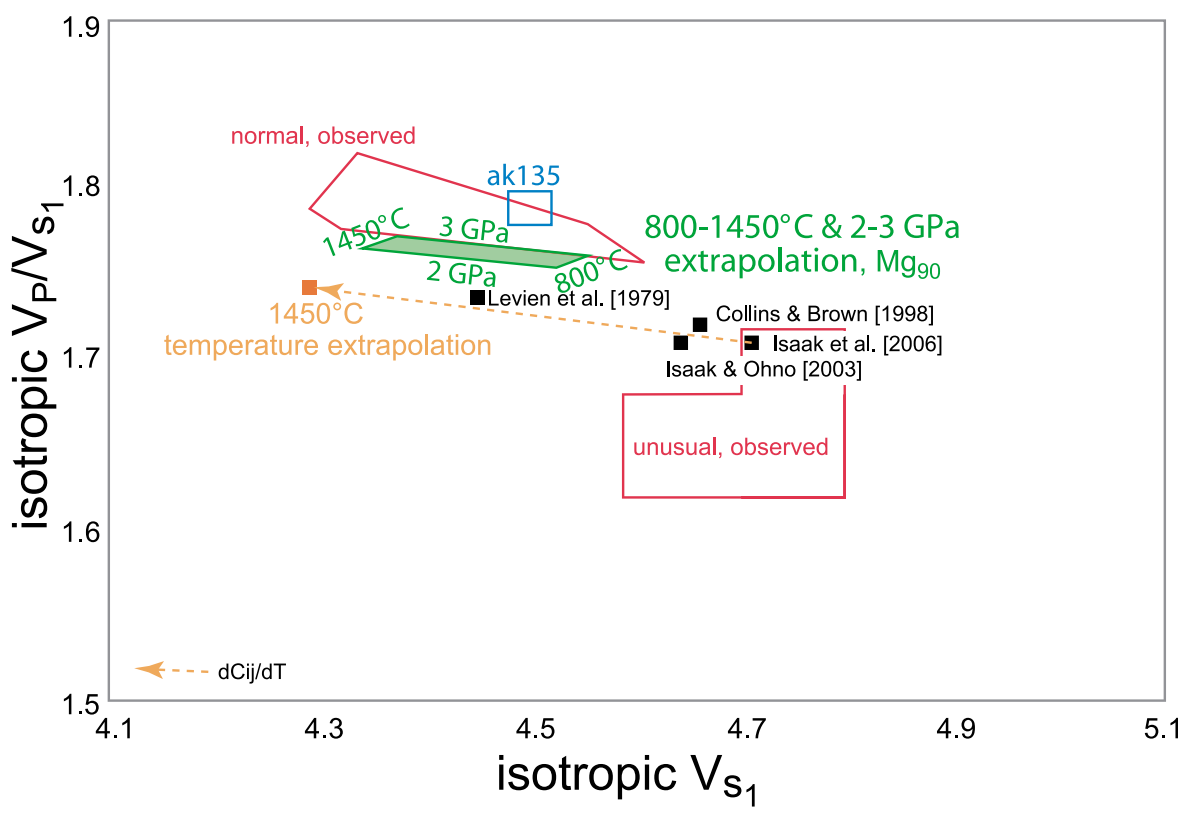

Figure 3. Clinopyroxene isotropic velocities. Unusual $\mathrm{S}$-wave speeds and $\mathrm{V}_{\mathrm{P}} / \mathrm{V}_{\mathrm{S}}$ ratios observed in subduction zones (red rectangles) cannot be explained using the isotropic velocities of magnesian clinopyroxene at i) STP (black squares) [Levien et al., 1979; Collins and Brown, 1998; Isaak and Ohno, 2003; Isaak et al., 2006] or ii) when extrapolated to $1200^{\circ} \mathrm{C}$ [Isaak et al., 2006]; there are no measurements of $\partial \mathrm{C}_{\mathrm{ij}} / \partial \mathrm{P}$ for clinopyroxene. These unusual velocities also cannot be explained by diopside $\left(\mathrm{Mg}_{90}\right)$ isotropic velocities extrapolated to $600-1200^{\circ} \mathrm{C}$ and 2-3 GPa (using the method of Hacker and Abers [2004] with the data of Isaak et al. [2006], Kandelin and Weidner [1988], and Zhang et al. [1997]).

$C_{i j}$, with 21 independent elements [Nye, 1957]. The VoigtReuss-Hill averages of the isotropic bulk modulus $K$ and the shear modulus $G$ [Hill, 1952] are

$$
\begin{gathered}
\mathrm{K}_{\text {Voigt }}=\left(\mathrm{C}_{11}+\mathrm{C}_{22}+\mathrm{C}_{33}+2 \mathrm{C}_{12}+2 \mathrm{C}_{13}+2 \mathrm{C}_{23}\right) / 9 \\
\mathrm{G}_{\text {Voigt }}=\left(\mathrm{C}_{11}+\mathrm{C}_{22}+\mathrm{C}_{33}-\mathrm{C}_{12}-\mathrm{C}_{13}-\mathrm{C}_{23}+3 \mathrm{C}_{44}+3 \mathrm{C}_{55}+3 \mathrm{C}_{66}\right) / 15 \\
\mathrm{~K}_{\text {Reuss }}=1 /\left(\mathrm{S}_{11}+\mathrm{S}_{22}+\mathrm{S}_{33}+2 \mathrm{~S}_{12}+2 \mathrm{~S}_{13}+2 \mathrm{~S}_{23}\right) \\
\mathrm{G}_{\text {Reuss }}=15 /\left(4 \mathrm{~S}_{11}+4 \mathrm{~S}_{22}+4 \mathrm{~S}_{33}-4 \mathrm{~S}_{12}-4 \mathrm{~S}_{13}-4 \mathrm{~S}_{23}+3 \mathrm{~S}_{44}+3 \mathrm{~S}_{55}+3 \mathrm{~S}_{66}\right) \\
\mathrm{K}_{\text {VRH }}=\left(\mathrm{K}_{\text {Voigt }}+\mathrm{K}_{\text {Reuss }}\right) / 2 \\
\mathrm{G}_{\text {VRH }}=\left(\mathrm{G}_{\text {Voigt }}+\mathrm{G}_{\text {Reuss }}\right) / 2
\end{gathered}
$$

where the compliance matrix $S_{i j}=C_{i j}^{-1}$. This section discusses isotropic averages or averaged properties; later sections address anisotropic materials. Because anisotropy leads to splitting and two $\mathrm{S}$ arrivals, we will refer to $S_{1}$ as the first, fast $\mathrm{S}$ arrival and $S_{2}$ as the second, slow arrival (or, $\mathrm{V}_{\mathrm{S} 1}$ and $\mathrm{V}_{\mathrm{S} 2}$ refer to the fast and slow wave speeds in a given propagation direction). These vary with propagation direction as determined by the eigenvalues of the Christoffel matrix [e.g., Maupin and Park, 2007].

\subsection{Isotropic Velocities of Olivine}

[7] The elastic properties and their temperature and pressure derivatives for forsterite [Isaak et al., 1989], fayalite [Speziale et al., 2004], and, especially $\mathrm{Fo}_{90}(90 \%$ forsterite, or Mg\#90) olivine [Isaak, 1992; Abramson et al., 1997], are among the best known for silicates. Velocities for $\mathrm{Fo}_{90}$ olivine at STP (standard temperature and pressure, $1 \mathrm{~atm}$ and $25^{\circ} \mathrm{C}$ ) are not expected to match high-pressure and hightemperature mantle-wedge velocities, and, indeed, do not (Figure 2, black squares). When laboratory-derived temperature derivatives of stiffnesses $\left(\partial C_{i j} / \partial T\right)$ are used to calculate velocities at elevated temperature (Figure 2, orange squares), however, the calculated velocities are close to ak135 and to those observed in typical mantle wedges (Figure 2, 'normal, observed') - although at lower $\mathrm{V}_{\mathrm{P}} / \mathrm{V}_{\mathrm{S}}$. When laboratoryderived pressure derivatives of stiffnesses $\left(\partial C_{i j} / \partial P\right)$ are used to calculate velocities at elevated pressure (Figure 2, orange circle), the $\mathrm{V}_{\mathrm{P}} / \mathrm{V}_{\mathrm{S}}$ are close to ak135 and to those observed in typical mantle wedges (Figure 2, 'normal, observed')though at higher $\mathrm{V}_{\mathrm{S}}$. When both $P$ and $T$ derivatives of stiffnesses $\left(\partial C_{i j} / \partial P\right.$ and $\left.\partial C_{i j} / \partial T\right)$ are used to calculate velocities at elevated pressure and temperature (Figure 2, green parallelogram, $800-1450^{\circ} \mathrm{C}$ and $2-3 \mathrm{GPa}$ ), the calculated velocities are close to ak135 and overlap with those observed in typical mantle wedges (Figure 2, 'normal, observed'). The unusually low $\mathrm{V}_{\mathrm{P}} / \mathrm{V}_{\mathrm{S}}$ ratios in the mantle wedge (Figure 2, 'unusual, observed') are significantly lower, however, indicating that they cannot be explained by the isotropic velocities of olivine at any expected pressure or temperature.

\subsection{Isotropic Velocities of Clinopyroxene}

[8] The elastic properties of clinopyroxene of a range of compositions have been measured at STP [Kandelin and Weidner, 1988; Collins and Brown, 1998; Isaak and Ohno, 2003; Nishihara et al., 2003]. The temperature derivatives $\partial \mathrm{C}_{\mathrm{ij}} / \partial \mathrm{T}$ [Isaak and Ohno, 2003; Isaak et al., 2006] and the pressure dependence of the bulk modulus, $\partial \mathrm{K} / \partial \mathrm{P}$, have been measured for diopside [Levien and Prewitt, 1981], but, to our knowledge, neither the pressure dependence of the stiffness matrix, $\partial \mathrm{C}_{\mathrm{ij}} / \partial \mathrm{P}$, nor even the pressure dependence of the isotropic shear modulus, $\partial \mathrm{G} / \partial \mathrm{P}$, have been measured. The green field in Figure 3 shows the combined effects of the measured temperature dependence for diopside, 


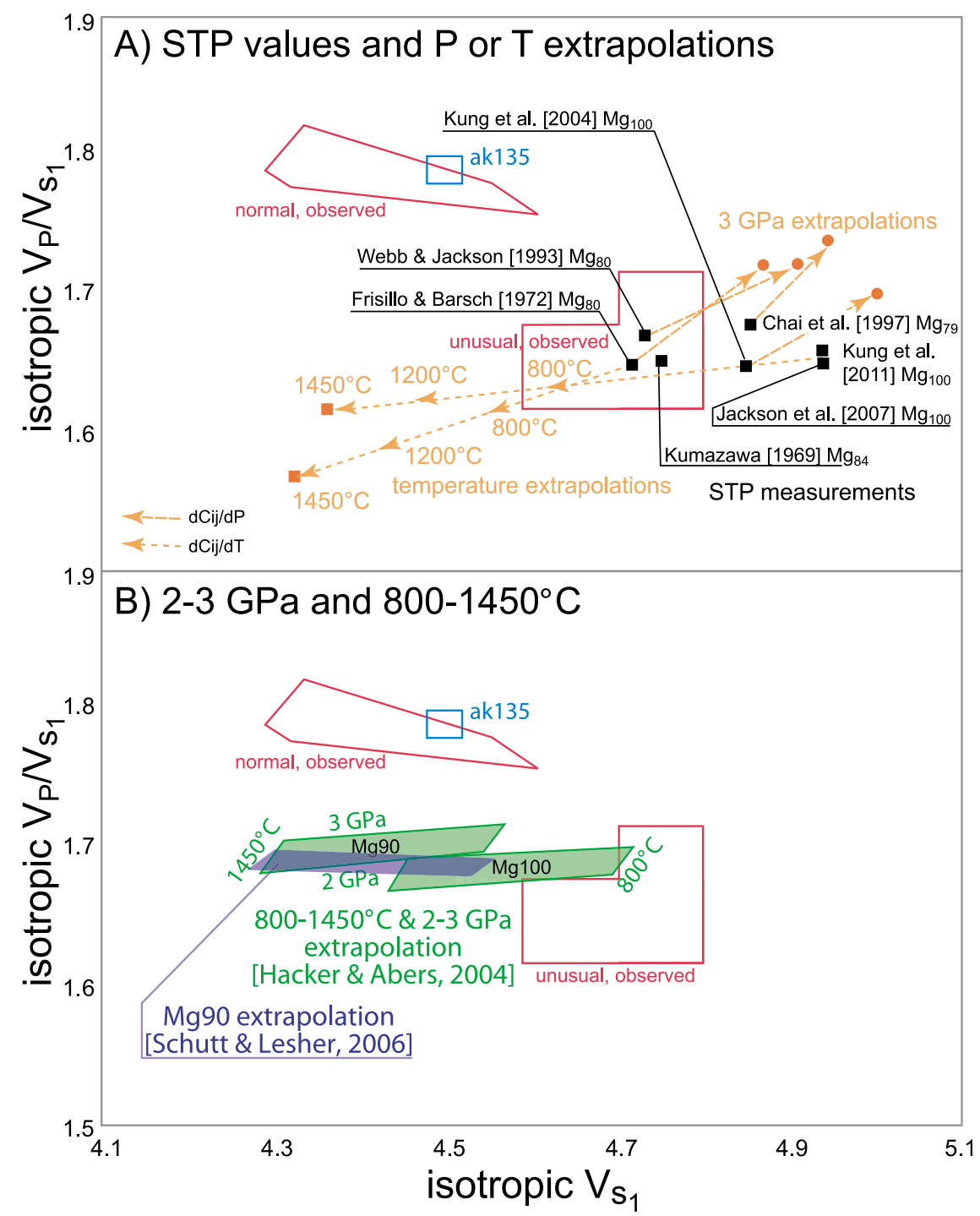

Figure 4. Orthopyroxene isotropic velocities. (a) Unusual $S$-wave speeds and $V_{P} / V_{S}$ ratios observed in subduction zones (red rectangles) cannot be explained using the isotropic velocities of magnesian orthopyroxene at i) STP (black squares) [Kumazawa, 1969; Frisillo and Barsch, 1972; Webb and Jackson, 1993; Chai et al., 1997a; Jackson et al., 2007; Kung et al., 2011]; ii) when extrapolated to $1200^{\circ} \mathrm{C}[$ Frisillo and Barsch, 1972; Jackson et al., 2007]; or iii) when extrapolated to $3 \mathrm{GPa}$ [Frisillo and Barsch, 1972; Webb and Jackson, 1993; Chai et al., 1997a; Kung et al., 2004]. (b) As noted by [Wagner et al., 2005, $2006,2008]$, these unusual velocities can be explained by enstatite $\left(\mathrm{Mg}_{100}\right)$ isotropic velocities extrapolated to $600-1200^{\circ} \mathrm{C}$ and 2-3 GPa (using the method of Hacker and Abers [2004] with the data of Kung et al. [2004] and Jackson et al. [2007]) or the method and data set of Schutt and Lesher [2006].

the measured pressure dependence of $\mathrm{K}$ for diopside and the pressure dependence of $\mathrm{G}$ for enstatite (see below). More measurements are warranted before a definitive conclusion can be reached, but the present data set indicates that regardless of the ambient pressure or temperature, the unusually low $\mathrm{V}_{\mathrm{P}} / \mathrm{V}_{\mathrm{S}}$ ratios in the mantle wedge cannot be explained by the isotropic velocities of clinopyroxene (Figure 3 ).

\subsection{Isotropic Velocities of Orthopyroxene}

[9] The elastic properties of $\mathrm{Mg}_{100}-\mathrm{Mg}_{79}$ orthopyroxene have been measured at STP [Kumazawa and Anderson, 1969; Duffy and Vaughan, 1988] and at elevated pressure [Frisillo and Barsch, 1972; Webb and Jackson, 1993; Chai et al., 1997b; Flesch et al., 1998; Shinmei et al., 1999; Angel and Jackson, 2002; Kung et al., 2004] and temperature [Frisillo and Barsch, 1972; Jackson et al., 2007; Kung et al., 2011]. Velocities for magnesian orthopyroxene at STP are not expected to match high-pressure and hightemperature mantle-wedge velocities, but, coincidentally, some match the unusual, low $\mathrm{V}_{\mathrm{P}} / \mathrm{V}_{\mathrm{S}}$ observations (Figure $4 \mathrm{a}$, black squares). When the three $\partial \mathrm{C}_{\mathrm{ij}} / \partial \mathrm{P}$ data sets [Frisillo and Barsch, 1972; Webb and Jackson, 1993; Chai et al., 1997b] are used to extrapolate Mg-orthopyroxene velocities to $3 \mathrm{GPa}$, the calculated $\mathrm{V}_{\mathrm{S}}$ and $\mathrm{V}_{\mathrm{P}} / \mathrm{V}_{\mathrm{S}}$ are greater than the observed values (orange circles). When the two $\partial \mathrm{C}_{\mathrm{ij}} / \partial \mathrm{T}$ data sets [Frisillo and Barsch, 1972; Jackson et al., 2007] 


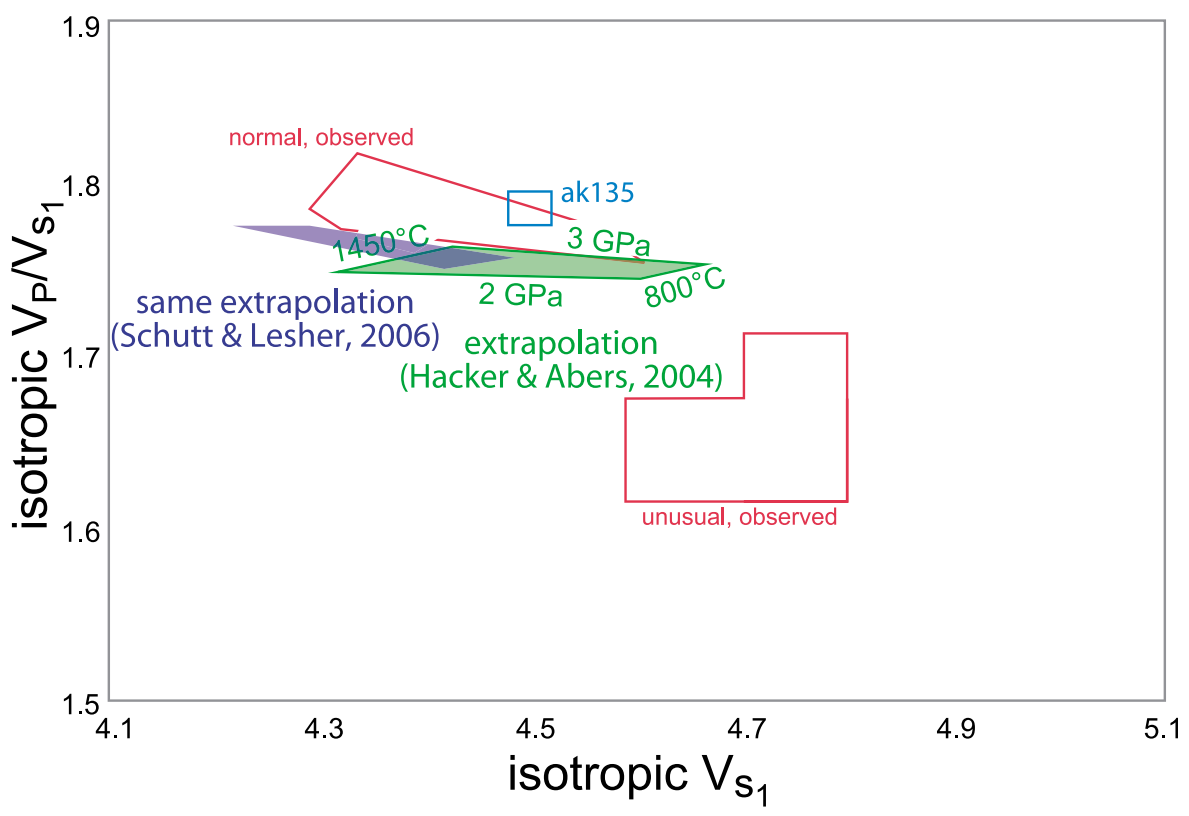

Figure 5. The calculated velocities of olivine-dominated peridotite expected in the upper mantle can have isotropic velocities similar to 'normal' mantle, but do not have isotropic velocities similar to those observed in the unusual, low $-\mathrm{V}_{\mathrm{P}} / \mathrm{V}_{\mathrm{S}}$ mantle wedges.

are used to extrapolate Mg-orthopyroxene velocities, the mismatch between the calculated and unusual observed values is small at temperatures less than $\sim 800^{\circ} \mathrm{C}$. (Note that at $1 \mathrm{~atm}, \mathrm{MgSiO}_{3}$ transforms from an orthorhombic to a monoclinic structure [Perrotta and Stephenson, 1965; Jackson et al., 2004] that is not seen at mantle-wedge conditions; here we use only the thermophysical properties of the orthorhombic polymorph.) Using the method of Hacker and Abers [2004] —which relies heavily on the Jackson et al. [2007] and Kung et al. [2011] data and employs Hashin-Shtrikman averaging - the velocities calculated for $\mathrm{Mg}_{100}$ orthopyroxene at $2 \mathrm{GPa}$ and $800-1200^{\circ} \mathrm{C}$ are close to the observed low- $\mathrm{V}_{\mathrm{P}} / \mathrm{V}_{\mathrm{S}}$ values (Figure $4 \mathrm{~b}$, green); using the Angel and Jackson [2002] values for $\mathrm{K}$ and $\partial \mathrm{K} / \partial \mathrm{P}$ produces only slightly different results. This concurrence has previously been emphasized by Wagner et al. [2005, 2006, 2008]. The same Hacker and Abers extrapolation for $\mathrm{Mg}_{90}$ orthopyroxene-which includes the data of Bass and Weidner [1984] - is not a good match to the observed $V_{S}$, nor is the extrapolation for $\mathrm{Mg}_{90}$ orthopyroxene using the method and data set of Schutt and Lesher [2006]. While $\mathrm{V}_{\mathrm{P}} / \mathrm{V}_{\mathrm{S}}$ is close to the unusual observed values, the extrapolated $V_{S}$ for orthopyroxene is $\sim 10 \%$ lower than observed. Moreover, because $\mathrm{Mg}_{90}$ — and not $\mathrm{Mg}_{100}$ (enstatite) — orthopyroxene is the composition expected for the upper mantle, these calculations imply that isotropic orthopyroxene is not the explanation for the unusual $\mathrm{V}_{\mathrm{P}} / \mathrm{V}_{\mathrm{S}}$ ratios in some mantle wedges.

\subsection{Summary: Isotropic Velocities of Unmetasomatized Mantle}

[10] As noted above, the mantle wedge is composed of $57-60 \%$ olivine, $16-27 \%$ orthopyroxene, $11-14 \%$ clinopyroxene, and $9-12 \%$ garnet. The calculated velocities of such mixtures at elevated $\mathrm{P}$ and $\mathrm{T}$ are compared in Figure 5 to the velocities observed in mantle wedges. It is clear that olivine-dominated peridotite expected in the upper mantle can have isotropic velocities similar to 'normal' mantle, but cannot have isotropic velocities similar to those observed in the unusual, low- $\mathrm{V}_{\mathrm{P}} / \mathrm{V}_{\mathrm{S}}$ mantle wedges. Most other effects, such as anelasticity at high temperatures and low frequencies [Faul and Jackson, 2005] or the presence of melt [e.g., Takei, 2002] tend to decrease $\mathrm{V}_{\mathrm{S}}$ and increase $\mathrm{V}_{\mathrm{P}} / \mathrm{V}_{\mathrm{S}}$, and would make these observations even harder to explain.

\section{Seismic Observations in Anisotropic Media}

[11] The $\mathrm{V}_{\mathrm{P}} / \mathrm{V}_{\mathrm{S}}$ ratio in Earth has been determined in a variety of ways, but primarily from local travel-time tomography and receiver functions [e.g., Wagner et al., 2005; Rossi et al., 2006; Wagner et al., 2008]. Tomography relying only upon teleseismic rays that travel from outside the image volume senses primarily variations in velocity and cannot easily constrain absolute $\mathrm{V}_{\mathrm{P}} / \mathrm{V}_{\mathrm{S}}$ ratios [e.g., Aki et al., 1977; Thurber and Ritsema, 2007], and thus studies that estimate only velocity perturbations are not considered further. (The novel waveform-modeling method of Zheng and Lay [2006] is also not considered here.) In the presence of anisotropy, two effects have the potential to bias estimated $V_{\mathrm{P}} / \mathrm{V}_{\mathrm{S}}$ ratios: the non-uniformity in ray geometry, and the relative sensitivity of measurements to fast versus slow shear wave speed. We consider both effects for routine arrival-time picks (the basic data for tomography) and for receiver functions.

\subsection{Ray Sampling Geometry}

[12] Receiver functions derive from teleseismic signals with a limited range of ray parameters $(0.04-0.08 \mathrm{~s} / \mathrm{km})$, so the ray angles are limited. At the conditions of interest $\left(\mathrm{V}_{\mathrm{S}}=\right.$ $\left.4.6-4.8 \mathrm{~km} / \mathrm{s}, \mathrm{V}_{\mathrm{P}} / \mathrm{V}_{\mathrm{S}}=1.65-1.70\right)$ and for subhorizontal interfaces generating conversions, these signals travel through the wedge with incidence angles of $11-23^{\circ}$ from vertical for $P$-to- $S$ conversions, and $18-41^{\circ}$ for direct $P$ arrivals. Ray bending for conversions generated by dipping 


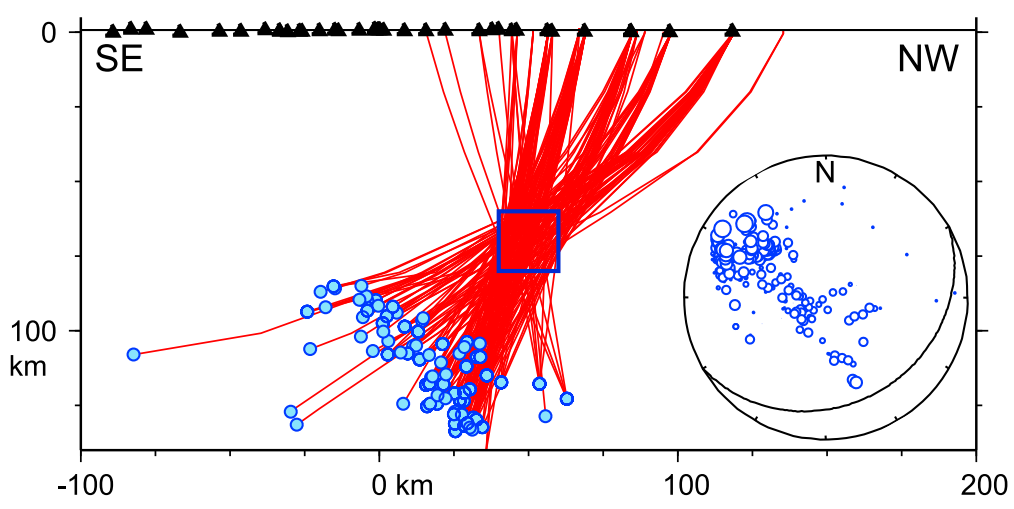

Figure 6. Ray coverage for one node in the Alaska wedge at $70 \mathrm{~km}$ depth [Rossi et al., 2006], showing orientation bias. Cross section shows earthquakes (circles), stations (triangles) and all rays sampling at least $10 \mathrm{~km}$ of the $20 \times 20 \mathrm{~km}$ block outlined by the blue rectangle, projected into the cross section. Note that some rays travel long distances along strike and the Wadati-Benioff zone is curved, making some earthquakes appear to lie low far below the main zone of seismicity. Inset shows upper-hemisphere stereonet projection of these ray orientations within the node (circles), with radius scaled to the length of the raypath within this $20 \times 20 \mathrm{~km}$ cell. Solid arc shows orientation of slab in upper-hemisphere projection. Most raypaths are either vertical or slab-normal.

interfaces will lead to a greater range of $S$ incidence angles, but in general the narrow range of incidence for $S$ leads to limited sampling of propagation directions. These methods constrain $\mathrm{V}_{\mathrm{P}} / \mathrm{V}_{\mathrm{S}}$ by comparing arrival times of the direct P-to-S conversion with the first mode-converted reverberations [Zhu and Kanamori, 2000]. As a result of the limited ray sampling, $\mathrm{V}_{\mathrm{P}} / \mathrm{V}_{\mathrm{S}}$ estimates based on these methods for subhorizontal interfaces or dipping interfaces [Rossi et al., 2006] are biased toward $P$ waves propagating vertically more than horizontally, and to $S$ waves with near-horizontal particle motion.

[13] For local travel-time tomography it is possible that the rays average sampling directions more uniformly. However, rays that illuminate the subduction-zone mantle wedge typically propagate upward from earthquakes within the WadatiBenioff zone to stations overlying it, so raypaths preferentially vary between near-vertical to slab-normal. To demonstrate this geometry bias, we plot rays sampling a single velocity node in the Alaska mantle wedge, imaged previously to have anomalous $\mathrm{V}_{\mathrm{P}} / \mathrm{V}_{\mathrm{S}}$ [Rossi et al., 2006] (Figure $6)$. For this node, $V_{S}=4.73$ and $V_{P} / V_{S}=1.65$ from tomography. The longest rays within the $20-\mathrm{km}$-sized node, which provide the strongest velocity constraint, generally travel vertically or perpendicular to the slab, and tend to lie in a plane perpendicular to the slab. Signals from these paths tend to have high amplitude and impulsive arrivals, compared with signals that travel long distances along strike, and so would likely dominate tomography for any array geometry. Presumably the longer paths are more affected by attenuation and scattering along the slab, and so are more emergent and used less often. In other words, there is a sampling bias that favors near-vertical to slab-normal rays, similar to receiver functions.

[14] Thus, anisotropic material with subhorizontal fast directions will typically produce slow $P$ waves and fast $S$ waves, provided that the $P$ and $S$ fast directions are parallel. This sampling will bias $\mathrm{V}_{\mathrm{P}} / \mathrm{V}_{\mathrm{S}}$ estimates toward low ratios relative to isotropic media. In the Alaska wedge, $S$-wave splitting data indicate a strike-parallel fast direction [Christensen and Abers, 2010]. If this is the orientation of the fast olivine axis (not vertical), then the $P$ waves may be biased to slower-than-isotropic velocities, whereas one direction of $S$ wave vibration always includes the fast direction. Although other data sets may have different sampling geometries, the distal parts of the mantle wedge will in general be sampled only by slab earthquakes recorded by stations above them, so similar biases are expected.

\subsection{Picking $\mathbf{S}$ Waves on Split Shear Waves}

[15] While practices vary, most local or regional S-wave arrival times are based on picks of the first arriving signal. Such practices take advantage of Fermat's Principle by associating the first, high-frequency arrival with the raytheoretical arrival, and avoid contamination with later scattered signals. If an $S$ wave propagates through anisotropic regions, however, it will be composed of fast and slow arrivals. On an arbitrarily oriented horizontal-component seismogram where both arrivals are present, the first arrival corresponds to the fast $\left(\mathrm{S}_{1}\right)$ shear velocity. Occasionally the component analyzed or the incident signal is naturally polarized parallel to the slow path, in which case the slow $\left(\mathrm{S}_{2}\right)$ velocity is sampled, but for all other polarized signals the first arrival is $\mathrm{S}_{1}$. In a few teleseismic studies, it has been possible to rotate signals into fast and slow directions before picking, resulting in two $\mathrm{S}$ picks [Hammond and Humphreys, 2000; Boyd et al., 2004], but this is rarely done with local data.

[16] To test for this effect, we examined the original seismograms that were picked for the travel-time tomography of Rossi et al. [2006]. The seismograms were rotated into fast and slow polarization directions as determined from shear wave splitting [Christensen and Abers, 2010]; high ( 8\%) anisotropy is inferred for the wedge, with the fast directions parallel to the slab strike, so the effect should be strong. The resulting seismograms were then compared with the original picks (Figure 7). Observed delay times reached up to a half 


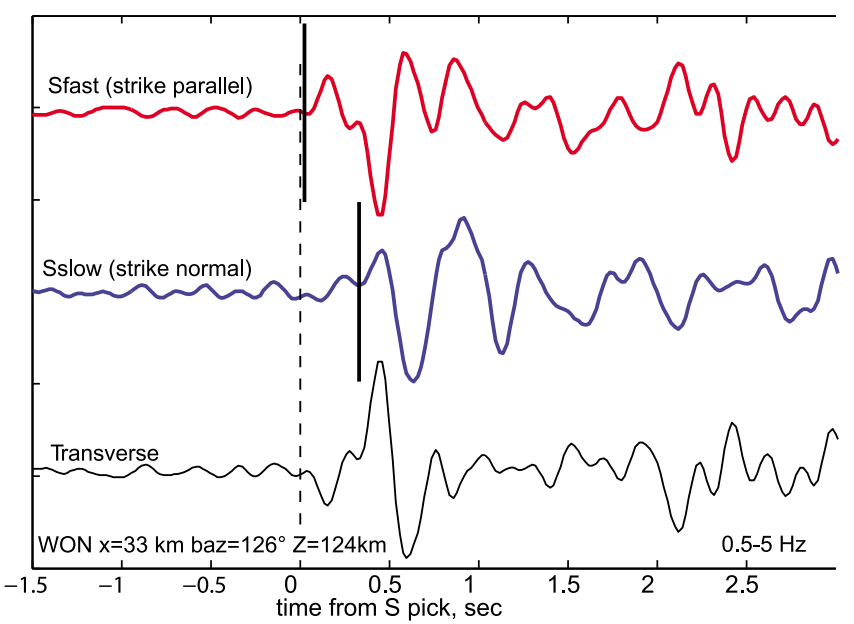

Figure 7. Example of a shear wave traversing the low $\mathrm{V}_{\mathrm{P}} / \mathrm{V}_{\mathrm{S}}$ part of the mantle wedge in Alaska. Bottom trace is the transverse component, from which the original [Rossi et al., 2006] pick was based. Top two traces show the $\mathrm{S}$ wave rotated into strike-parallel and strike-perpendicular polarizations, corresponding to anisotropic fast and slow directions, respectively, from shear wave splitting analysis [Christensen and Abers, 2010]. Dashed line shows picked arrival time used to estimate $\mathrm{V}_{\mathrm{S}}$ and $\mathrm{V}_{\mathrm{P}} / \mathrm{V}_{\mathrm{S}}$; it corresponds to the fast $\mathrm{S}$ arrival, about $0.3 \mathrm{~s}$ before the slow $\mathrm{S}$ arrival. Solid lines show picked $\mathrm{S}_{1}$ and $\mathrm{S}_{2}$ arrivals.

second, and in all cases the picked arrival time used for tomography (dashed line) corresponds to the first, fastdirection arrival. Because the rays generally travel vertically more than horizontally (see previous section) they often lie within the shear wave window for which $\mathrm{S}$ waves are sensitive to azimuthal anisotropy. Hence, the S-wave travel times tend to be most sensitive to $\mathrm{V}_{\mathrm{S} 1}$ not $\mathrm{V}_{\mathrm{S} 2}$.

[17] Cross-correlation methods for picking arrivals match the peak energy rather than the first arriving pulse, so they should include both the $S_{1}$ and $S_{2}$ arrivals, weighted by amplitude. Cross-correlation arrivals only give relative arrival times, so even for methods that can use them [Zhang et al., 2004] it is not clear that they would constrain absolute $\mathrm{V}_{\mathrm{P}} / \mathrm{V}_{\mathrm{S}}$ without additional information. Receiver functions similarly "fit" peak energy via deconvolution, and so may represent averages of $S_{1}$ and $S_{2}$, although at lower frequencies than local earthquake tomography. In the Alaska example, both receiver-function and tomographic estimates of $\mathrm{V}_{\mathrm{P}} / \mathrm{V}_{\mathrm{S}}$ are similar [Rossi et al., 2006], suggesting that biases still exist. In most subduction zones receiver-function estimates are dominated by signals that travel along strike, because most teleseismic sources lie along strike of circumPacific subduction zones, so radial-component receiver functions should preferentially sample $S_{1}$. The receiver function source distribution may produce sampling biases, obviating the averaging benefits of fitting peak energy.

\section{Anisotropic Velocities of Peridotite}

\subsection{Velocity Anisotropy of Olivine}

[18] Olivine, like all minerals, has anisotropic elastic properties [Verma, 1960], and therefore olivine-rich rocks with crystal preferred orientations (CPOs) have anisotropic velocities [Hess, 1964]. At least five CPO types with dominant slip systems have been identified in olivine [e.g., Ben Ismail and Mainprice, 1998; Jung et al., 2006], although only four are orthorhombic, 'plane-strain type' (the fifth, type-D, CPO is produced by [100] $\{0 \mathrm{kl}\}$ slip equivalent to mixed type-A and type-E CPOs). The CPOs develop under different combinations of stress, temperature, and $\mathrm{H}_{2} \mathrm{O}$ content (see summary in Karato et al. [2008]). We calculated the velocities for an olivine single crystal at $800^{\circ} \mathrm{C}, 1200^{\circ} \mathrm{C}$, and $1450^{\circ} \mathrm{C}$ and $3 \mathrm{GPa}$ (Figure 8) using the elastic stiffnesses, $C_{i j}$, and $\partial C_{i j} / \partial P$ and $\partial C_{i j} / \partial T$ from Abramson et al. [1997] and Isaak [1992], and the software of Mainprice [1990, 2005]. Figure 8 shows the relative abundances of the $V_{S 1}$ and $\mathrm{V}_{\mathrm{P}} / \mathrm{V}_{\mathrm{S} 1}$ ratios for 'all' (actually, 960 evenly spaced) directions through an olivine single crystal, where " $\mathrm{S}_{1}$ " corresponds to the fast pseudo-S velocity, and $\mathrm{S}_{2}$ to the slow $\mathrm{S}$ velocity. As discussed above, seismic travel-time tomography may be biased toward $\mathrm{S}_{1}$. The most-abundant values are shown in warm colors, and the least in cold colors. The pale colors show the relative abundances for all propagation directions, whereas the dark colors show the abundances of $\mathrm{V}_{\mathrm{S} 1}$ and $\mathrm{V}_{\mathrm{P}} / \mathrm{V}_{\mathrm{S} 1}$ ratios for near-vertically incident waves $\left(35^{\circ}\right.$ from vertical; i.e., a typical sampling window) for olivine single crystals corresponding to CPO types A, B, C, and $\mathrm{E}$ in the nomenclature of Jung et al. [2006], where the flow plane and flow direction are horizontal. If the flow plane is vertical, the $\mathrm{A}$ and $\mathrm{E}$ maxima simply exchange positions and the $\mathrm{B}$ and $\mathrm{C}$ maxima do likewise: thus, the sampling window velocities for all possible orientations of olivine single crystals with a horizontal flow axis are defined by the maxima shown. Figure 8 demonstrates that the unusually low $\mathrm{V}_{\mathrm{P}} / \mathrm{V}_{\mathrm{S}}$ ratios observed in some mantle wedges can be explained by wave propagation through olivine single crystals. Below we show that this is also true for orthopyroxene. Then, because the mantle is polycrystalline, we show that this conclusion holds true for rocks.

\subsection{Velocity Anisotropy of Orthopyroxene}

[19] Stiffness matrices, $C_{i j}$, have been measured for two compositions of orthopyroxene [Chai et al., 1997b; Jackson et al., 2007]. At STP, the velocities of waves passing through orthopyroxene in all possible directions are much faster than observed in mantle wedges (Figure 9). (The velocities and velocities ratios for orthopyroxene are less variable than olivine, which has greater elastic anisotropy.) When extrapolated to $3 \mathrm{GPa}$ and $1200^{\circ} \mathrm{C}$ using $\partial \mathrm{C}_{\mathrm{ij}} / \partial \mathrm{P}$ from $W e b b$ and Jackson [1993] or Chai et al. [1997a], the velocities of waves passing through $\mathrm{Mg}$-orthopyroxene have a broad range - some of which match the unusually low $\mathrm{V}_{\mathrm{P}} / \mathrm{V}_{\mathrm{S}}$ ratios observed in some mantle wedges. Note, compared with isotropic velocities shown in Figure 4, that extrapolation to temperatures $>1200^{\circ} \mathrm{C}$ pushes the calculated velocities to lower $\mathrm{V}_{\mathrm{S} 1}$ and lower $\mathrm{V}_{\mathrm{P}} / \mathrm{V}_{\mathrm{S} 1}$.

\subsection{Velocity Anisotropy of Deformed Peridotite}

[20] Naturally and experimentally deformed peridotite samples have measured CPOs with typical strengths of 515 times random [see subsequent references]. Do such peridotites have $\mathrm{V}_{\mathrm{P}} / \mathrm{V}_{\mathrm{S}}$ ratios as low as $\sim 1.65$ ? Although the CPOs of many peridotites have been measured, only a few studies have reported sufficient information (specifically $C_{i j}$ for rocks) to calculate velocity anisotropy. Figure 10 shows 


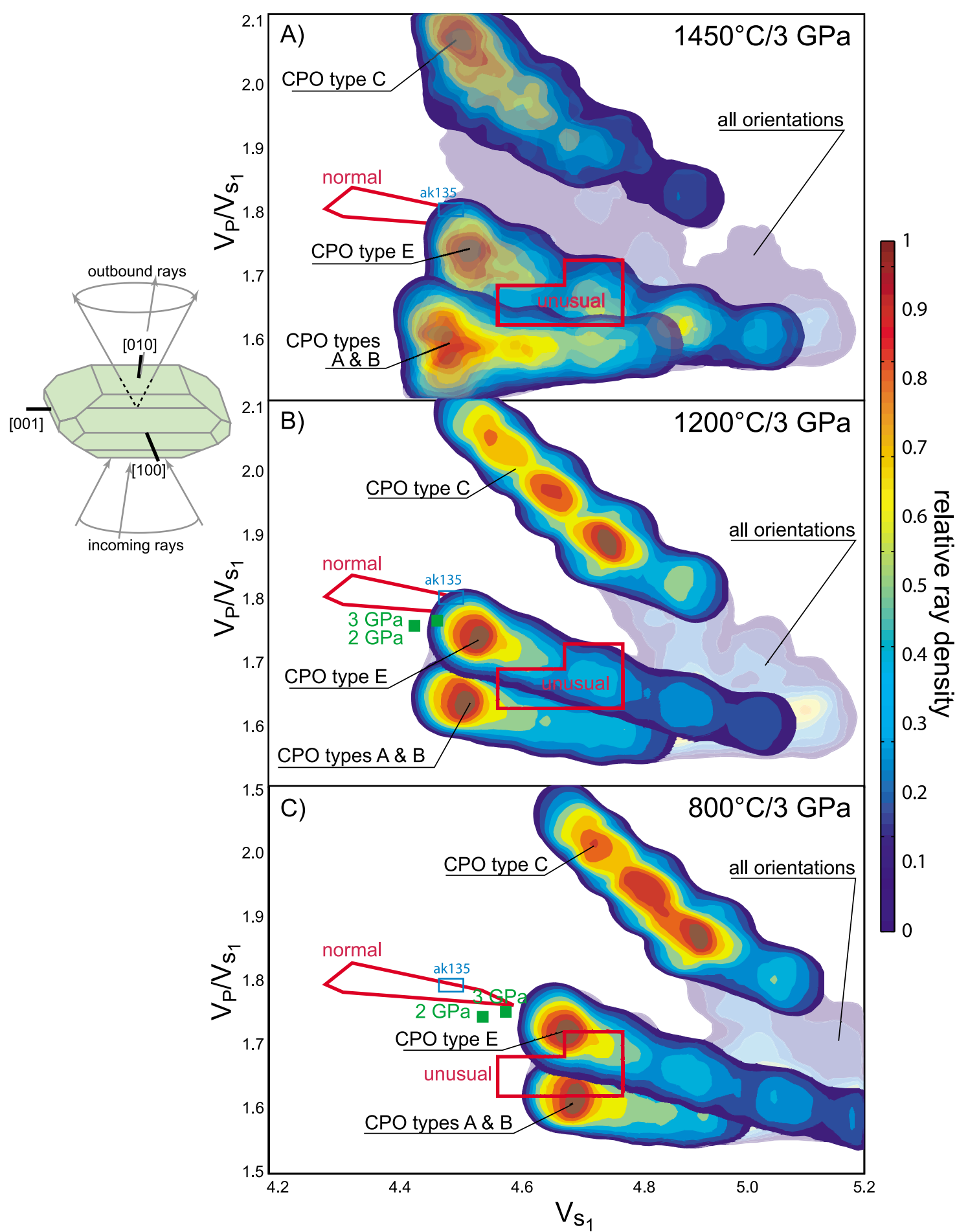

Figure 8. Olivine single-crystal velocity anisotropy at (a) $1450^{\circ} \mathrm{C}$, (b) $1200^{\circ} \mathrm{C}$, and (c) $800^{\circ} \mathrm{C}$. S-wave speeds and $\mathrm{V}_{\mathrm{P}} / \mathrm{V}_{\mathrm{S}}$ ratios observed in some subduction zones (red rectangles) can be explained by the velocities of $\mathrm{Mg}_{90}$ olivine single crystals. The range of values for waves passing through all possible orientations of $\mathrm{Mg}_{90}$ olivine crystals is shown in faded colors. Waves rising through the 'sampling' window (a $35^{\circ}$ downward-opening cone) and passing through different types of single-crystal orientations are shown in dark colors, with the warmest color representing a ray density ten times that of the coldest color. The best match is for type-A [100](010) and type-B [001](010) orientations; type E [100](001) is less likely, and type $\mathrm{C}[001](100)$ is impossible. The diagram on the left shows the geometry for rays passing through an olivine crystal in the orientation appropriate for subhorizontal type-A or type-B slip. $\mathrm{C}_{\mathrm{ij}}$ computations made using [Isaak, 1992] and [Abramson et al., 1997]. Olivine slip planes are assumed to be horizontal with respect to Earth's surface. 


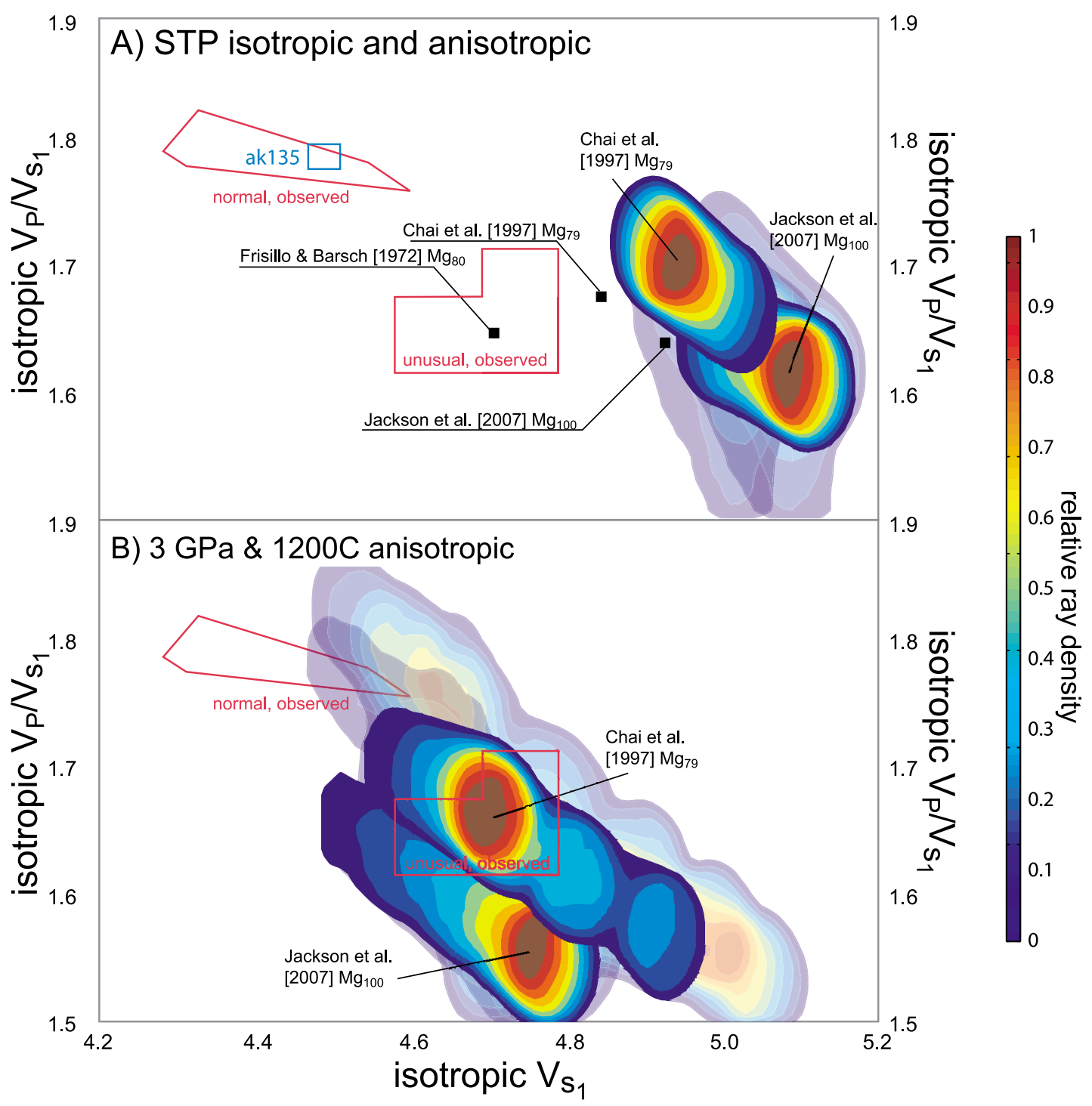

Figure 9. ( $\mathrm{a}$ and $\mathrm{b}$ ) Orthopyroxene single-crystal velocity anisotropy. The range of velocities for waves passing through all possible orientations of $\mathrm{Mg}_{100}$ and $\mathrm{Mg}_{79}$ crystals is shown in faded colors. The velocities of waves rising through the 'sampling' window (a $35^{\circ}$ downward-opening cone) and passing through all possible single-crystal orientations are shown in bold colors.

the calculated velocities for near-vertically incident waves for i) an average of 5 type-A CPOs from continental peridotite xenoliths [Mainprice and Silver, 1993], ii) an average of 72 type-D CPOs from ophiolites [Ben Ismail and Mainprice, 1998], iii) an average of 13 type-D CPOs from arc xenoliths [Ben Ismail and Mainprice, 1998], iv) an average of 17 type-D CPOs from subcontinental peridotite xenoliths [Ben Ismail and Mainprice, 1998], v) an average of 14 type-E CPOs from a subarc peridotite massif [Mehl et al., 2003], vi) an average of 15 type-A CPOs from continental peridotite xenoliths [Pera et al., 2003], vii) an average of 13 type-A CPOs from continental peridotite xenoliths [Vauchez et al., 2005], and viii) a B-type CPO from a subcontinental peridotite massif [Skemer et al., 2006]. In the two studied peridotite massifs, the shear plane is subhorizontal, but Figures 10a and 10b show horizontal and vertical shear planes to provide a comprehensive evaluation. (The velocities and velocities ratios for rocks (Figure 10) are less variable than single crystals (Figures 8 and 9) simply because of the 'averaging' effects of crystals of different orientations.) At STP (Figure 10a and 10b), the velocities of peridotite with measured CPOs are a good match for the unusual $\mathrm{V}_{\mathrm{P}} / \mathrm{V}_{\mathrm{S}}$ ratiosbut not $\mathrm{V}_{\mathrm{S}}$-measured in some mantle wedges. Which of these specific CPO types might be most relevant to the mantle wedge is poorly understood; Karato et al. [2008] favored the development of types $\mathrm{B}, \mathrm{C}$, and $\mathrm{E}$ within the wedge.

[21] To extrapolate the same data to pressures and temperatures relevant to mantle wedges requires knowing the orientation of every grain in the rock as well as the $C_{i j}$ for each mineral at elevated pressure and temperature. In general, such data are not available in the literature; typically only the rock $C_{i j}$ at some chosen $\mathrm{P}$ and $\mathrm{T}$ are presented. For the Mehl et al. data of Figure 10 we have the complete orientation information, so we were able to calculate velocities using single-crystal $C_{i j}$ extrapolated to high $\mathrm{P}$ and T. For the other data sets in Figure 10 , only $C_{i j}$ - not complete crystal 


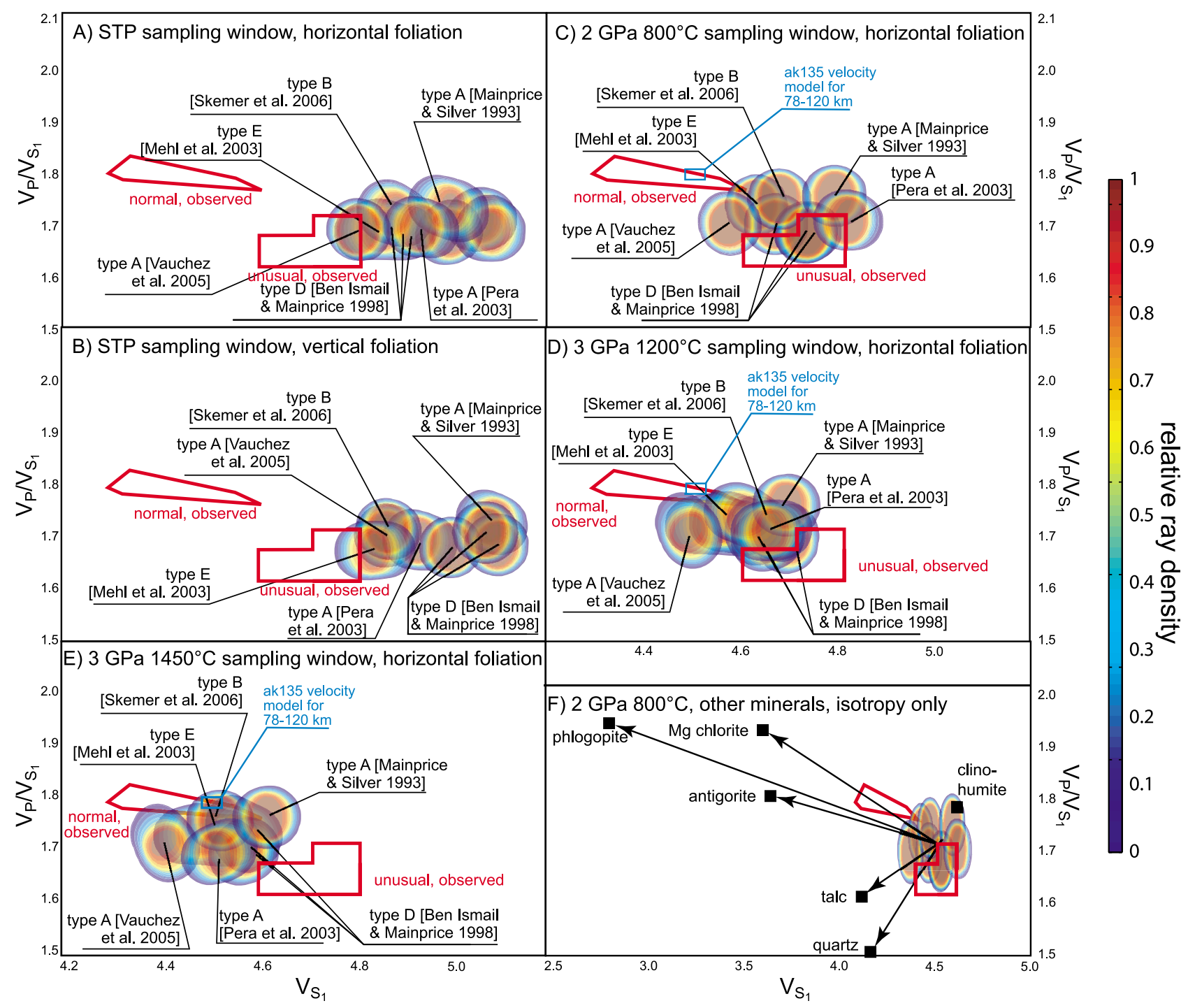

Figure 10. Peridotite velocity anisotropy. (a-e) Calculated velocities for peridotite CPOs [Mainprice and Silver, 1993; Ben Ismail and Mainprice, 1998; Mehl et al., 2003; Pera et al., 2003; Vauchez et al., 2005; Skemer et al., 2006] generally do not match the unusual S-wave speeds and $\mathrm{V}_{\mathrm{P}} / \mathrm{V}_{\mathrm{S}}$ ratios observed in some subduction zones (red box); the closest match is for horizontal foliations at $2-3 \mathrm{GPa}$ and $900-1200^{\circ} \mathrm{C}$. (f) Mixtures of peridotite (including more orthopyroxene-rich varieties) and talc or quartz provide possible matches $\mathrm{S}$-wave speeds and $\mathrm{V}_{\mathrm{P}} / \mathrm{V}_{\mathrm{S}}$ ratios observed in some subduction zones.

orientations - were available, and only for one PT condition (3-3.5 $\mathrm{GPa}$ and $900-1050^{\circ} \mathrm{C}$ for Mainprice and Silver [1993], $0.3 \mathrm{GPa}$ and $1000^{\circ} \mathrm{C}$ for Ben Ismail and Mainprice [1998], $0.5 \mathrm{GPa}$ and $1000^{\circ} \mathrm{C}$ for Pera et al. [2003], and $3 \mathrm{GPa}$ and $800^{\circ} \mathrm{C}$ for Skemer et al. [2006]). For those cases, the extrapolation of the given rock $\mathrm{C}_{\mathrm{ij}}$ to other PT conditions was done using Isaak [1992] and Abramson et al. [1997], ignoring the minor $C_{i j}$ terms where $\mathrm{i}, \mathrm{j}=4 . .6$ and $\mathrm{i} \neq \mathrm{j}$, and ignoring the $\mathrm{P}$ and $\mathrm{T}$ dependence of $C_{i j}$ for pyroxene; comparison of Figures $2-4$ (particularly $\partial \mathrm{C}_{\mathrm{ij}} / \partial \mathrm{T}$ ) indicates that this results in an overestimate of $\mathrm{V}_{\mathrm{P}} / \mathrm{V}_{\mathrm{S}}$, but has little effect on $\mathrm{V}_{\mathrm{S}}$. Note that none of the other data sets are gravely disparate from the Mehl et al. data, suggesting that these necessary simplifications are not damaging to the conclusions. The results (Figure 10) show that, when extrapolated to pressures and temperatures relevant to mantle wedges, some peridotites with measured CPOs have $\mathrm{V}_{\mathrm{P}} / \mathrm{V}_{\mathrm{S}}$ and $\mathrm{V}_{\mathrm{S}}$ that are a reasonable match to the unusual observed values at $2 \mathrm{GPa}$ and $800^{\circ} \mathrm{C}$, and some are a reasonable match to ak135 and normally observed values at $3 \mathrm{GPa}$ and $1450^{\circ} \mathrm{C}$, typical of ambient mantle away from subduction zones. Thus, the difference between typical and unusual $\mathrm{V}_{\mathrm{P}} / \mathrm{V}_{\mathrm{S}}$ ratios in mantle wedges may simply be an effect of pressure and temperature in peridotite with oriented minerals.

\section{Isotropic Velocities in Rocks Other Than Peridotite}

[22] Rocks other than peridotite may be present in the mantle wedge and could potentially explain the low $\mathrm{V}_{\mathrm{P}} / \mathrm{V}_{\mathrm{S}}$ observations. 


\subsection{Quartz}

[23] Because quartz has an extremely low Poisson's ratio [even negative at temperatures below the $\alpha-\beta$ transition [Ohno, 1995; Lakshtanov et al., 2007], a number of recent seismological studies [Eberhart-Phillips et al., 2006; Rossi et al., 2006; Zheng and Lay, 2006] have suggested that alpha quartz might be the cause of low $\mathrm{V}_{\mathrm{P}} / \mathrm{V}_{\mathrm{S}}$ in the mantle wedge. This suggestion has to satisfy three conditions. 1) Crustal rocks with sufficient free quartz have such high inherent buoyancy when immersed in peridotite [Behn et al., 2011] that the mantle lithosphere would have to be viscous enough to keep them from rising out of the mantle wedge [Gerya and Meilick, 2011]. 2) At $3 \mathrm{GPa}$, alpha quartz is only stable between $1000^{\circ} \mathrm{C}$ and $1342^{\circ} \mathrm{C}$ [Holland and Powell, 1998], being supplanted by coesite at lower temperatures and by beta quartz at higher temperatures, and both of these phases have 'normal' $\mathrm{V}_{\mathrm{P}} / \mathrm{V}_{\mathrm{S}}$ ratios $>1.7$. Only if the quartz $\rightarrow$ coesite or alpha $\rightarrow$ beta transitions are sufficiently more sluggish than inferred from experiments [Day et al., 1914; Mosenfelder and Bohlen, 1997] could alpha quartz be preserved outside this temperature range. 3) Peridotite is sufficiently silica undersaturated that an enormous influx of silica is required to stabilize free quartz over a volume large enough to be detectable with seismic waves. Specifically, if depleted-MORB mantle (DMM) is metasomatized by pure $\mathrm{SiO}_{2}, \sim 0.3$ moles of $\mathrm{SiO}_{2}$ must be added to every mole of peridotite to stabilize free quartz at $1200^{\circ} \mathrm{C}$ and $3 \mathrm{GPa}$.

[24] To assess whether this degree of $\mathrm{SiO}_{2}$ metasomatism is feasible, we can estimate the rate at which $\mathrm{SiO}_{2}$ is transferred from subducting slab to mantle wedge by i) hydrous fluid and ii) sediment diapirs. For a slab dipping $45^{\circ}$ beneath a $40-\mathrm{km}$ thick crust, the mantle wedge to a depth of $100 \mathrm{~km}$ has a volume of $3600 \mathrm{~km}^{3}$ per $\mathrm{km}$ of trench, or a mass of $\sim 12 \mathrm{E} 6 \mathrm{~kg} / \mathrm{km}$. At $1200^{\circ} \mathrm{C}$ and $3 \mathrm{GPa}, \mathrm{DMM}$ is $\sim 5 \mathrm{~mol} / \mathrm{kg}$, meaning that the wedge contains $\sim 60 \mathrm{E} 6 \mathrm{~mol} / \mathrm{km}$. The flux of $\mathrm{H}_{2} \mathrm{O}$ expelled globally from subducting slabs at depths of $\sim 15-100 \mathrm{~km}$ is $\sim 1 \mathrm{E} 13 \mathrm{~kg} / \mathrm{Myr} / \mathrm{km}$ of trench [Hacker, 2008]. Such fluids have $\sim 1$ moles Si per kg of $\mathrm{H}_{2} \mathrm{O}$ [Manning, 2004; Wohlers et al., 2011], meaning that they could carry $\sim 1 \mathrm{E} 13$ moles $/ \mathrm{km} / \mathrm{Myr}$ of Si into the mantle wedge. To metasomatize a $10 \mathrm{~km} \times 10 \mathrm{~km}$-square cross-section of the mantle wedge to the point where quartz first appears would require that all of this Si-rich fluids over $\sim 150 \mathrm{Myr}$ is deposited in that $10-\mathrm{km}$ square. If the fluid is instead distributed evenly throughout the wedge, the first appearance of free quartz will be delayed 36 times longer $\left(3600 \mathrm{~km}^{2} / 100 \mathrm{~km}^{2}\right)$.

[25] An alternative to fluid-driven metasomatism, $\mathrm{SiO}_{2}$ might be introduced to the mantle wedge by melts [Spandler et al., 2010] or diapirs from subducting slabs [Behn et al., 2011; Gerya and Meilick, 2011]. Notably, the two subduction zones for which unusually low $\mathrm{V}_{\mathrm{P}} / \mathrm{V}_{\mathrm{S}}$ has been reported - central Chile and Alaska-are among the subduction zones for which Behn et al. calculated that sediment diapirs will initiate at the shallowest depths and lowest temperatures (this select group includes Cascadia, N Sumatra, and N Hikurangi-sites where unusually low $\mathrm{V}_{\mathrm{P}} / \mathrm{V}_{\mathrm{S}}$ might be sought as a further test of this idea). As an example of the possible magnitude of this effect, the Alaska trench is subducting sediment with an average $\mathrm{SiO}_{2}$ content of $61 \mathrm{wt} \%$ [Plank and Langmuir, 1998] at a rate of $79 \mathrm{~km}^{3} / \mathrm{Myr} / \mathrm{km}$
[Clift and Vannucchi, 2004]. If all this material rises diapirically into the wedge, it displaces a $\sim 9 \times 9 \mathrm{~km}$ square cross-section of the mantle wedge every million years. Beneath northern Chile, sediment + ablated continental crust are being subducted at a rate of $28 \mathrm{~km}^{3} / \mathrm{Myr} / \mathrm{km}$ [Clift and Vannucchi, 2004]; this slower rate of $\mathrm{SiO}_{2}$ subduction would fill the same size cross section in $\sim 3$ Myr.

[26] Whether sediment is sufficiently abundant in mantle wedges - either as diapirs or layers - is unknown. There are no outcrops that have ever been interpreted to have resulted from such a process, but rare xenoliths demonstrate that crustal rocks do reach mantle depths in convergence zones [Hacker et al., 2005].

\subsection{Orthopyroxene}

[27] The other main phase that has been suggested to be responsible for low $\mathrm{V}_{\mathrm{P}} / \mathrm{V}_{\mathrm{S}}$ ratios is enstatite [Wagner et al., 2005, 2006, 2008]. This suggestion seems more appealing than quartz because DMM already contains $\sim 15$ vol\% orthopyroxene, and by the time that DMM reaches $\mathrm{SiO}_{2}$ saturation and free quartz begins to form, metasomatized DMM consists of 85 vol\% orthopyroxene (calculations with Perple_X [Connolly and Petrini, 2002]). This suggestion also has limitations, however. 1) Relative to DMM, only at $\sim 600-900^{\circ} \mathrm{C}$ does orthopyroxene have the 'correct' $\mathrm{V}_{\mathrm{S}}$ (Figure 9) - although this discrepancy is not large and is a reason for further refining both mantle-wedge velocities and the elastic properties of orthopyroxene polycrystals at high pressure and temperature. 2) The orthopyroxene in typical upper mantle peridotite is not enstatite $\left(\mathrm{Mg}_{100}\right)$, but has an Mg\# of 93-85 (see above); orthopyroxenes of such compositions have $\mathrm{S}$-wave velocities that are too slow (Figure 4b). 3) The same $\mathrm{SiO}_{2}$ flux arguments that pertain to quartz also apply to orthopyroxene-although to a lesser degree.

\subsection{Other Minerals}

[28] Other phases that might be present where the mantle wedge is metasomatized include chlorite, phlogopite, antigorite, clinohumite, and talc (Figure 10f). At $3 \mathrm{GPa}$, chlorite is stable in peridotite to $750-800^{\circ} \mathrm{C}$ [Fumagalli and Poli, 2005; Till et al., 2011] and antigorite to $640-690^{\circ} \mathrm{C}$ [Bromiley and Pawley, 2003], so either or both could be present in the low $-\mathrm{V}_{\mathrm{P}} / \mathrm{V}_{\mathrm{S}}$ region of the Chile mantle wedge for example. Chlorite, phlogopite and antigorite have elevated isotropic $\mathrm{V}_{\mathrm{P}} / \mathrm{V}_{\mathrm{S}}$ ratios and cannot be responsible for the observed low $\mathrm{V}_{\mathrm{P}} / \mathrm{V}_{\mathrm{S}}$ ratios if they are randomly oriented. Single crystals of chlorite, phlogopite and antigorite have calculated $\mathrm{V}_{\mathrm{P}} / \mathrm{V}_{\mathrm{S}}$ ratios as low as 1.4-1.2 [Aleksandrov and Ryzhova, 1961; Bezacier et al., 2010], however, indicating that oriented chlorite, phlogopite and/or antigorite in metasomatized peridotite could produce the observed low $V_{P} / V_{S}$ ratios at $\mathrm{T}<700-800^{\circ} \mathrm{C}$.

[29] Fluorinated Ti-clinohumite (Figure 10f) is stable in peridotite to at least $1000^{\circ} \mathrm{C}$ at $3 \mathrm{GPa}$ [Hermann et al., 2007], but it is uncommon and its elastic properties are incompletely determined. $K$ and $G$ have been measured for a natural Mg\#93 and F-bearing clinohumite [Fritzel and Bas, 1997]; assuming $K^{\prime}=4$ leads to $\mathrm{V}_{\mathrm{S}}=4.6$ and $\mathrm{V}_{\mathrm{P}} / \mathrm{V}_{\mathrm{S}} \sim 1.8$ at $3 \mathrm{GPa} /$ $800^{\circ} \mathrm{C}$. The bulk modulus and $K^{\prime}$ for Ti- and F-free, $\mathrm{Mg} \# 100$ clinohumite have been measured [Ross and Crichton, 2001]; assuming the same Poisson's ratio as the natural clinohumite 


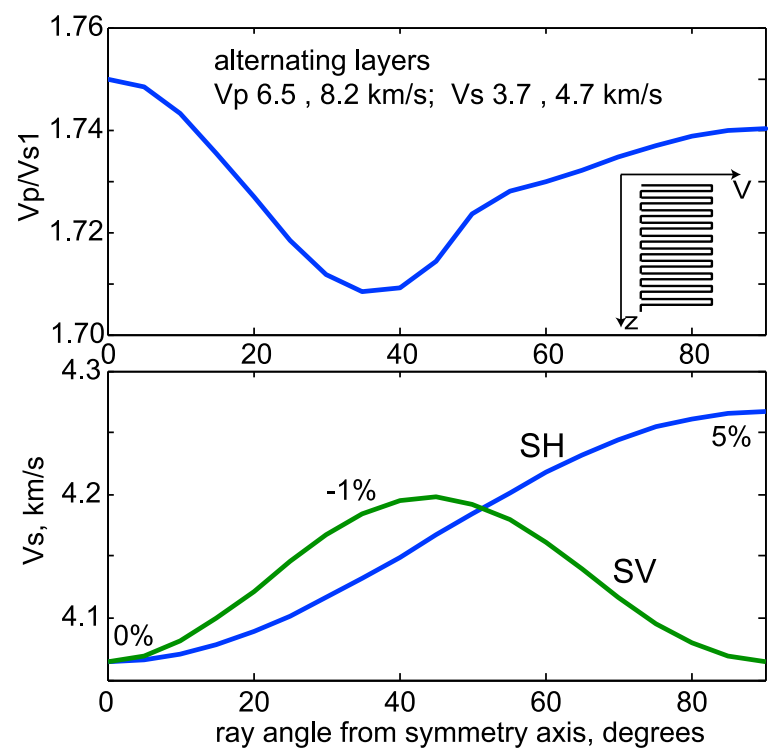

Figure 11. Effective velocities for a laminated stack of isotropic layers of equal thickness with very different velocities $\left(\mathrm{V}_{\mathrm{P}}\right.$ varying between 6.5 and $8.2 \mathrm{~km} / \mathrm{s}, \mathrm{V}_{\mathrm{P}} / \mathrm{V}_{\mathrm{S}}=1.75$, and densities of $2800,3300 \mathrm{~kg} / \mathrm{m}^{3}$ ), averaged following Backus [1962], as a function of incident ray angle relative to symmetry axis. (top) $\mathrm{Vp} / \mathrm{Vs} 1$ where Vs1 is the fastest $\mathrm{S}$ velocity. (bottom) The two $\mathrm{S}$ velocities. Anisotropy, labeled, varies from -1 to $+5 \%$ with ray angle. Horizontal layers in this manner could explain low $\mathrm{V}_{\mathrm{P}} / \mathrm{V}_{\mathrm{S}}$ at some ray angles and high anisotropy observed by horizontally propagating waves.

leads to $\mathrm{V}_{\mathrm{S}}=4.4$ and $\mathrm{V}_{\mathrm{P}} / \mathrm{V}_{\mathrm{S}} \sim 1.81$ at $3 \mathrm{GPa} / 800^{\circ} \mathrm{C}$. In both cases, the calculated $\mathrm{V}_{\mathrm{P}} / \mathrm{V}_{\mathrm{S}}$ are too high.

[30] Talc is stable in peridotite to $\sim 600^{\circ} \mathrm{C}$, but its elastic properties are poorly known. Babeyko et al. [1994] assumed a Poisson's ratio of 0.275 (equivalent to $\mathrm{V}_{\mathrm{P}} / \mathrm{V}_{\mathrm{S}}=1.80$ ), like other sheet silicates. Bailey and Holloway [2000] derived a similar value for G, but Mainprice et al. [2008] argued that the probability of a CPO in Bailey's samples renders that number suspect. Mainprice et al. [2008] used ab initio methods to calculate the elastic properties of talc, obtaining isotropic STP ratios for $\mathrm{V}_{\mathrm{P}} / \mathrm{V}_{\mathrm{S}}$ of 1.54 and 1.59 for the two polytypes of talc. These values are so low that a mixture of talc and peridotite might produce the right combination of $\mathrm{V}_{\mathrm{S}}$ and $\mathrm{V}_{\mathrm{P}} / \mathrm{V}_{\mathrm{S}}$. However, this would require mantle wedge temperatures $<600^{\circ} \mathrm{C}$, far less than inferred from seismic attenuation and thermal models, particularly in Alaska [Abers et al., 2006].

\section{Layered Anisotropy}

[31] Even for isotropic materials, layering can produce effective anisotropy if the seismic wavelengths significantly exceed that of the layering [Backus, 1962]. Horizontal layering can give rise to anisotropy similar to that observed and, for the same reasons as discussed above, slight biases toward low $\mathrm{V}_{\mathrm{P}} / \mathrm{V}_{\mathrm{S}}$ ratios. To illustrate this effect, we calculate a Backus average of a stack of layers with two alternating compositions, equal in thickness, with $\mathrm{V}_{\mathrm{P}} / \mathrm{V}_{\mathrm{S}}=1.75$ for both, but $\mathrm{V}_{\mathrm{P}}$ alternating between $6.5 \mathrm{~km} / \mathrm{s}$ and $8.2 \mathrm{~km} / \mathrm{s}$
(Figure 11). The $8.2 \mathrm{~km} / \mathrm{s}$ layers could represent normal mantle at $800^{\circ} \mathrm{C}$, whereas the lower velocity might represent intermixed, low-velocity anomalous material. At angles of $30-45^{\circ}$ from the symmetry axis, as sampled by local tomography or receiver functions, $\mathrm{V}_{\mathrm{P}} / \mathrm{V}_{\mathrm{S}}$ drops from 1.75 to 1.71. Although this effect does not produce anisotropies consistent with shear wave splitting, it could constitute nearly half of the difference in $V_{\mathrm{P}} / \mathrm{V}_{\mathrm{S}}$ observed between typical and unusual mantle wedges. The main difficulty in invoking this mechanism is the extreme $(20 \%)$ variations in seismic velocity needed over distances that are small compared with wavelengths of seismic waves $(\ll 1 \mathrm{~km}$, for local earthquake tomography). It is difficult to envision a material with such elastic heterogeneity existing in the mantle wedge; velocity differences between most coexisting materials are not so great.

\section{Conclusions}

[32] Low $V_{\mathrm{P}} / \mathrm{V}_{\mathrm{S}}$ ratios seem to be a robust, if local, observation in subduction zone mantle wedges. They may be partly attributable to sampling biases and methodologies inherent in most seismological methods used to make these measurements: raypaths preferentially are subvertical, and $\mathrm{S}_{1}$ is measured more easily than $\mathrm{S}_{2}$. Two classes of material seem consistent with the observation of low $V_{P} / V_{S}$. The first, massive silica addition to stabilize quartz, requires enormous $\mathrm{SiO}_{2}$ flux into the wedge and a narrow temperature range in which alpha quartz is stable. Alternatively, the low $\mathrm{V}_{\mathrm{P}} / \mathrm{V}_{\mathrm{S}}$ ratios could reflect the presence of anisotropic peridotites with subhorizontal foliations and fast directions. Because such anisotropic fabrics are well documented in peridotite xenoliths and massifs, this explanation is the simplest. In the two subduction zones with well-documented low $\mathrm{V}_{\mathrm{P}} / \mathrm{V}_{\mathrm{S}}$ wedges, shallow dip should result in relatively subhorizontal flow throughout the wedge, perhaps enhancing the bias of seismic observations.

[33] These $V_{P} / V_{S}$ ratio variations, when used in tandem with measurements of anisotropy (e.g., shear wave splitting), might provide powerful constraints on mantle composition and fabric that cannot be achieved from one set of measurements alone. For example, once the splitting fast direction is known, travel times of both $\mathrm{S}_{1}$ and $\mathrm{S}_{2}$ can be included in velocity inversions, and anisotropic models that are consistent with petrologically plausible fabrics could be favored. At a minimum, any model of the mantle wedge must be consistent with both sets of observations, something that we have shown is non-trivial. More generally, anisotropy and shear wave splitting affect most observations used to infer seismic velocities and could be taken into account when making those observations. For example, it may be productive to measure two shear wave arrival times rather than just the first arrival - particularly in cases where the horizontal fabric orientation is constrained - to allow velocity inversions to explicitly incorporate anisotropy parameters. While this has been done on a small number of teleseismic data sets [Hammond and Toomey, 2003; Boyd et al., 2004], it is not generally done for local earthquake data sets.

[34] These results provide some understanding of low $\mathrm{V}_{\mathrm{P}} / \mathrm{V}_{\mathrm{S}}$ estimates in Alaska and northern Chile, but do not explain why such low $\mathrm{V}_{\mathrm{P}} / \mathrm{V}_{\mathrm{S}}$ values are not seen in other 
subduction zones, except perhaps in patches [Zhao et al., 2009]. Both of these zones feature shallowly dipping slabs and no volcanism. A gently inclined slab may promote subhorizontal foliation development and (perhaps) increased anisotropy; this seems to be the case for Alaska. Raypaths through the wedge above steeply dipping slabs may lie more parallel to the foliation than perpendicular to it, giving higher $\mathrm{V}_{\mathrm{P}} / \mathrm{V}_{\mathrm{S}}$ ratios. The latter may prevent the development of patches or columns of very high $\mathrm{V}_{\mathrm{P}} / \mathrm{V}_{\mathrm{S}}$, as observed in Nicaragua where melting is extensive [Syracuse et al., 2008].

[35] Acknowledgments. Reviewed by David Mainprice, Lara Wagner, and anonymous. Sarah Brownlee provided a helpful review and much help with MATLAB code. Lucile Bezacier, Phil Skemer and Alain Vauchez kindly shared data. Alain and David Mainprice provided considerable help with software. Derek Schutt graciously loaned his code and database for making the Schutt and Lesher calculations shown in Figure 5. Funded by NSF EAR0545399 and NSF EAR-0745620.

\section{References}

Abers, G. A., P. E. van Keken, E. A. Kneller, A. Ferris, and J. C. Stachnik (2006), The thermal structure of subduction zones constrained by seismic imaging: Implications for slab dehydration and wedge flow, Earth Planet. Sci. Lett., 241, 387-397, doi:10.1016/j.eps1.2005.11.055.

Abramson, E. H., J. M. Brown, L. J. Slutsky, and J. Zang (1997), The elastic constants of San Carlos olivine to $17 \mathrm{GPa}, J$. Geophys. Res., 102 12,253-12,263, doi:10.1029/97JB00682.

Aki, K., A. Christoffersson, and E. S. Husebye (1977), Determination of the three-dimensional seismic structure of the lithosphere, J. Geophys. Res., 82, 277-296, doi:10.1029/JB082i002p00277.

Aleksandrov, K. S., and T. V. Ryzhova (1961), Elastic properties of rock-forming minerals, II. Layered silicates, Bull. Acad. Sci. U.S.S.R., Geophys. Ser., 12, 871-875.

Angel, R. J., and J. M. Jackson (2002), Elasticity and equation of state of orthoenstatite, $\mathrm{MgSiO}_{3}$, Am. Mineral., 87, 558-561.

Babeyko, A. Y., S. V. Sobolev, E. D. Sinelnikov, Y. P. Smirnov, and N. A Derevschikova (1994), Calculation of elastic properties in lower part of the Kola borehole from bulk chemical compositions of core samples, Surv. Geophys, 15, 545-573, doi:10.1007/BF00690174.

Backus, G. E. (1962), Long-waveelastic anisotropy produced by horizontal layering, J. Geophys. Res., 67, 4427-4440, doi:10.1029/JZ067i011p04427.

Bailey, E., and J. R. Holloway (2000), Experimental determination of elastic properties of talc to $800^{\circ} \mathrm{C}, 0.5 \mathrm{GPa}$; calculations of the effect on hydrated peridotite, and implications for cold subduction zones, Earth Planet. Sci. Lett., 183, 487-498, doi:10.1016/S0012-821X(00)00288-0.

Bass, J. D., and D. J. Weidner (1984), Elasticity of single-crystal orthoferrosilite, J. Geophys. Res., 89(B6), 4359-4371, doi:10.1029/JB089iB06p04359.

Behn, M. D., P. B. Kelemen, G. Hirth, B. R. Hacker, and H. J. Massonne (2011), Diapirs as the source of the sediment signature in arc lavas, Nat. Geosci., 4, 641-646, doi:10.1038/ngeo1214.

Ben Ismail, W., and D. Mainprice (1998), An olivine fabric database: An overview of upper mantle fabrics and seismic anisotropy, Tectonophysics, 296, 145-157, doi:10.1016/S0040-1951(98)00141-3.

Bezacier, L., B. Reynard, J. D. Bass, C. Sanchez-Valle, and B. Van de Moortèle (2010), Elasticity of antigorite, seismic detection of serpentinites, and anisotropy in subduction zones, Earth Planet. Sci. Lett., 289 198-208, doi:10.1016/j.epsl.2009.11.009.

Boyd, O. S., C. H. Jones, and A. F. Sheehan (2004), Foundering lithosphere imaged beneath the southern Sierra Nevada, California, USA, Science, 305, 660-662 doi:10.1126/science.1099181.

Bromiley, G. D., and A. R. Pawley (2003), The stability of antigorite in the systems $\mathrm{MgO}-\mathrm{SiO}_{2}-\mathrm{H}_{2} \mathrm{O}(\mathrm{MSH})$ and $\mathrm{MgO}-\mathrm{Al}_{2} \mathrm{O}_{3}-\mathrm{SiO}_{2}-\mathrm{H}_{2} \mathrm{O}$ (MASH) The effects of $\mathrm{Al}_{3}+$ substitution on high-pressure stability, Am. Mineral., $88,99-108$

Chai, M., J. M. Brown, and L. J. Slutsky (1997a), The elastic constants of a pyrope-grossular-almandine garnets to $20 \mathrm{GPa}$, Geophys. Res. Lett., 24, 523-526, doi:10.1029/97GL00371.

Chai, M., J. M. Brown, and L. J. Slutsky (1997b), The elastic constants of an aluminous orthopyroxene to $12.5 \mathrm{GPa}, J$. Geophys. Res., 102(B7), 14,779-14,785, doi:10.1029/97JB00893.

Christensen, D. H., and G. A. Abers (2010), Seismic anisotropy under central Alaska from SKS splitting observations, J. Geophys. Res., 115 B04315, doi:10.1029/2009JB006712.
Clift, P., and P. Vannucchi (2004), Controls on tectonic accretion versus erosion in subduction zones: Implications for the origin and recycling of the continental crust, Rev. Geophys., 42, RG2001, doi:10.1029/ 2003RG000127.

Collins, M. D., and J. M. Brown (1998), Elasticity of an upper mantle clinopyroxene, Phys. Chem. Miner., 26(1), 7-13, doi:10.1007/s002690050156.

Connolly, J. A. D., and K. Petrini (2002), An automated strategy for calculation of phase diagram sections and retrieval of rock properties as a function of physical conditions, J. Metamorph. Geol., 20, 697-708, doi:10.1046/j.1525-1314.2002.00398.x.

Day, A. L., R. B. Sosman, and J. C. Hostetter (1914), The determination of mineral and rock densities at high temperatures, Am. J. Sci., 37, 1-39, doi:10.2475/ajs.s4-37.217.1.

Duffy, T. S., and M. T. Vaughan (1988), Elasticity of enstatite and its relationship to crystal structure, J. Geophys. Res., 93(B1), 383-391, doi:10.1029/JB093iB01p00383.

Eberhart-Phillips, D., D. H. Christensen, T. M. Brocher, R. Hansen, N. A Ruppert, P. J. Haeussler, and G. A. Abers (2006), Imaging the transition from Aleutian subduction to Yakutat collision in central Alaska, with local earthquakes and active source data, J. Geophys. Res., 111, B11303, doi:10.1029/2005JB004240.

Faul, U. H., and I. Jackson (2005), The seismological signature of temperature and grain size variations in the upper mantle, Earth Planet. Sci. Lett., 234, 119-134, doi:10.1016/j.eps1.2005.02.008.

Flesch, L. M., B. S. Li, and R. C. Liebermann (1998), Sound velocities of polycrystalline $\mathrm{MgSiO}_{3}$-orthopyroxene to $10 \mathrm{GPa}$ at room temperature, Am. Mineral., 83, 444-450.

Frisillo, A. L., and G. R. Barsch (1972), Measurement of single-crystal elastic constants of bronzite as a function of pressure and temperature, J. Geophys. Res., 77(32), 6360-6384, doi:10.1029/JB077i032p06360.

Fritzel, T. L. B., and J. D. Bas (1997), Sound velocities of clinohumite, and implications for water in Earth's upper mantle, Geophys. Res. Lett., 24 1023-1026, doi:10.1029/97GL00946.

Fumagalli, P., and S. Poli (2005), Experimentally determined phase relations in hydrous peridotites to $6.5 \mathrm{GPa}$ and their consequences on the dynamics of subduction zones, J. Petrol., 46, 555-578, doi:10.1093/ petrology/egh088.

Gerya, T. V., and F. I. Meilick (2011), Geodynamic regimes of subduction under an active margin: Effects of rheological weakening by fluids and melts, J. Metamorph. Geol., 29, 7-31, doi:10.1111/j.1525-1314.2010. 00904.x

Gutscher, M.-A., R. Maury, J.-P. Eissen, and E. Bourdon (2000), Can slab melting be caused by flat subduction?, Geology, 28, 535-538, doi:10.1130/0091-7613(2000)28<535:CSMBCB $>2.0 . \mathrm{CO} ; 2$

Hacker, B. R. (2008), $\mathrm{H}_{2} \mathrm{O}$ subduction beyond arcs, Geochem. Geophys. Geosyst., 9, Q03001, doi:10.1029/2007GC001707.

Hacker, B. R., and G. A. Abers (2004), Subduction Factory 3: An Excel worksheet and macro for calculating the densities, seismic wave speeds, and $\mathrm{H}_{2} \mathrm{O}$ contents of minerals and rocks at pressure and temperature, Geochem. Geophys. Geosyst., 5, Q01005, doi:10.1029/2003GC000614.

Hacker, B. R., P. Luffi, V. Lutkov, V. Minaev, L. Ratschbacher, T. Plank, M. Ducea, A. Patiño-Douce, M. McWilliams, and J. Metcalf (2005), Nearultrahigh pressure processing of continental crust: Miocene crustal xenoliths from the Pamir, J. Petrol., 46, 1661-1687, doi:10.1093/petrology/ egi030.

Hammond, W. C., and E. D. Humphreys (2000), Upper mantle seismic wave velocity: Effects of realistic partial melt geometries, J. Geophys. Res., 105, 10,975-10,986, doi:10.1029/2000JB900041

Hammond, W. C., and D. R. Toomey (2003), Seismic velocity anisotropy and heterogeneity beneath the Mantle Electromagnetic and Tomography Experiment (MELT) region of the East Pacific Rise from analysis of $P$ and $S$ body waves, J. Geophys. Res., 108(B4), 2176, doi:10.1029/ 2002JB001789.

Hermann, J., J. D. Fitz Gerald, N. Malaspina, A. J. Berry, and M. Scambelluri (2007), OH-bearing planar defects in olivine produced by the breakdown of Ti-rich humite minerals from Dabie Shan (China), Contrib. Mineral. Petrol. 153, 417-428, doi:10.1007/s00410-006-0155-7.

Hess, H. H. (1964), Seismic anisotropy of the uppermost mantle under oceans, Nature, 203, 629-631, doi:10.1038/203629a0.

Hill, R. (1952), The elastic behaviour of a crystalline aggregate, Proc. Phys Soc. London, Sect. A , 65, 349-354, doi:10.1088/0370-1298/65/5/307.

Holland, T. J. B., and R. Powell (1998), An internally consistent thermodynamic data set for phases of petrological interest, J. Metamorph. Geol., 16, 309-343, doi:10.1111/j.1525-1314.1998.00140x.

Isaak, D. G. (1992), High-temperature elasticity of iron-bearing olivines, J. Geophys. Res., 97, 1871-1885, doi:10.1029/91JB02675.

Isaak, D. G., and I. Ohno (2003), Elastic constants of chrome-diopside: Application of resonant ultrasound spectroscopy to monoclinic single- 
crystals, Phys Chem Miner, 30, 430-439, doi:10.1007/s00269-003$0334-2$.

Isaak, D. G., O. L. Anderson, and T. Goto (1989), Elasticity of single-crystal forsterite measured to $1700 \mathrm{~K}, J$. Geophys. Res., 94, 5895-5906, doi:10.1029/JB094iB05p05895.

Isaak, D. G., I. Ohno, and P. C. Lee (2006), The elastic constants of monoclinic single-crystal chrome-diopside to $1,300 \mathrm{~K}$, Phys. Chem. Miner., 32(10), 691-699, doi:10.1007/s00269-005-0047-9.

Jackson, J. M., S. V. Sinogeikin, M. A. Carpenter, and J. D. Bass (2004), Novel phase transition in orthoenstatite, Am. Mineral., 89, 239-245.

Jackson, J. M., S. V. Sinogeikin, and J. D. Bass (2007), Sound velocities and single-crystal elasticity of orthoenstatite to $1073 \mathrm{~K}$ at ambient pressure, Phys. Earth Planet. Inter., 161(1-2), 1-12, doi:10.1016/j.pepi.2006. 11.002 .

Jung, H., I. Katayama, Z. Jiang, T. Hiraga, and S. Karato (2006), Effect of water and stress on the lattice-preferred orientation of olivine, Tectonophysics, 421, 1-22, doi:10.1016/j.tecto.2006.02.011.

Kandelin, J., and D. J. Weidner (1988), Elastic properties of hedenbergite, J. Geophys. Res., 93, 1063-1072, doi:10.1029/JB093iB02p01063.

Karato, S.-I., H. Jung, I. Katayama, and P. Skemer (2008), Geodynamic significance of seismic anisotropy of the upper mantle; new insights from laboratory studies, Annu. Rev. Earth Planet. Sci., 36, 59-95, doi:10.1146/ annurev.earth.36.031207.124120

Kennett, B. L. N., E. R. Engdahl, and R. Buland (1995), Constraints on seismic velocities in the Earth from travel times, Geophys. J. Int., 122, 108-124, doi:10.1111/j.1365-246X.1995.tb03540.x.

Kumazawa, M. (1969), The elastic constants of single-crystal orthopyroxene, J. Geophys. Res., 74(25), 5973-5980, doi:10.1029/JB074i025p05973.

Kumazawa, M., and O. L. Anderson (1969), Elastic moduli, pressure derivatives, and temperature derivatives of single-crystal olivine and singlecrystal forsterite, J. Geophys. Res., 74, 5961-5972, doi:10.1029/ JB074i025p05961.

Kung, J., B. Li, T. Uchida, Y. Wang, D. Neuville, and R. C. Liebermann (2004), In situ measurements of sound velocities and densities across the orthopyroxene $\rightarrow$ high-pressure clinopyroxene transition in $\mathrm{MgSiO}_{3}$ at high pressure, Phys. Earth Planet. Inter., 147, 27-44, doi:10.1016/ j.pepi.2004.05.008.

Kung, J., I. Jackson, and R. C. Liebermann (2011), High-temperature elasticity of polycrystalline orthoenstatite $\left(\mathrm{MgSiO}_{3}\right)$, Am. Mineral., 96 , 577-585, doi:10.2138/am.2011.3632.

Lakshtanov, D. L., S. V. Sinogeikin, and J. D. Bass (2007), High-temperature phase transitions and elasticity of silica polymorphs, Phys. Chem Miner., 34(1), 11-22, doi:10.1007/s00269-006-0113-y.

Levien, L., and C. T. Prewitt (1981), High-pressure structural study of diopside, Am. Mineral., 66, 315-323.

Levien, L., D. J. Weidner, and C. T. Prewitt (1979), Elasticity of diopside, Phys. Chem. Miner., 4(2), 105-113, doi:10.1007/BF00307555.

Mainprice, D. A. (1990), A FORTRAN program to calculate seismic anisotropy from the lattice preferred orientation of minerals, Comput. Geosci. 16, 385-393, doi:10.1016/0098-3004(90)90072-2.

Mainprice, D. (2005), Pfch5, CAREWARE, U. N. Nations Children's Fund, New York. [Available at ftp://www.gm.univ-montp2.fr/mainprice// CareWare Unicef Programs/.]

Mainprice, $\bar{D}$., and $\bar{P}$. G. Silver (1993), Interpretation of SKS-waves using samples from the subcontinental lithosphere, Phys. Earth Planet. Inter., 78, 257-280, doi:10.1016/0031-9201(93)90160-B.

Mainprice, D., Y. Le Page, J. Rodgers, and P. Jouanna (2008), Ab initio elastic properties of talc from 0 to $12 \mathrm{GPa}$ : Interpretation of seismic velocities at mantle pressures and prediction of auxetic behaviour at low pressure, Earth Planet. Sci. Lett., 274(3-4), 327-338, doi:10.1016/j.epsl.2008. 07.047.

Manning, C. E. (2004), The chemistry of subduction-zone fluids, Earth Planet. Sci. Lett., 223, 1-16, doi:10.1016/j.epsl.2004.04.030.

Maupin, V., and J. Park (2007), Theory and observations: Wave propagation in anisotropic media, in Treatise on Geophysics, vol. 1, Seismology and Structure of the Earth, edited by B. Romanowicz and A. Dziewonski, pp. 289-321, Elsevier, New York.

Mehl, L., B. R. Hacker, G. Hirth, and P. B. Kelemen (2003), Arc-parallel flow within the mantle wedge: Evidence from the accreted Talkeetna arc, south central Alaska, J. Geophys. Res., 108(B8), 2375, doi:10.1029/ 2002JB002233.

Mosenfelder, J. L., and S. R. Bohlen (1997), Kinetics of the cœsite to quartz transformation, Earth Planet. Sci. Lett., 153, 133-147, doi:10.1016 S0012-821X(97)00159-3.

Nishihara, Y., E. Takahashi, K. Matsukage, and T. Kikegawa (2003), Thermal equation of state of omphacite, Am. Mineral., 88, 80-86.

Nye, J. F. (1957), Physical Properties of Crystals, 322 pp., Clarendon, Oxford, U. K.
Ohno, I. (1995), Temperature variation of elastic properties of $\alpha$-quartz up to the $\alpha-\beta$ transition, J. Phys. Earth, 43, 157-169, doi:10.4294/ jpe 1952.43.157.

Pera, E., D. Mainprice, and L. Burlini (2003), Anisotropic seismic properties of the upper mantle beneath the Torre Alfina area (northern Apennines, central Italy), Tectonophysics, 370(1-4), 11-30, doi:10.1016/S00401951(03)00175-6

Perrotta, A. J., and D. A. Stephenson (1965), Clinoenstatite: High-low inversion, Science, 148, 1090-1091, doi:10.1126/science.148.3673.1090.

Plank, T., and C. H. Langmuir (1998), The chemical composition of subducting sediment and its consequences for the crust and mantle, Chem. Geol., 145, 325-394, doi:10.1016/S0009-2541(97)00150-2.

Ross, N. L., and W. L. Crichton (2001), Compression of synthetic hydroxylclinohumite $\quad\left[\mathrm{Mg}_{9} \mathrm{Si}_{4} \mathrm{O}_{16}(\mathrm{OH})_{2}\right]$ and hydroxylchondrodite, $\left[\mathrm{Mg}_{5} \mathrm{Si}_{2} \mathrm{O}_{8}(\mathrm{OH})_{2}\right]$, Am. Mineral., 86, 990-996.

Rossi, G., G. A. Abers, S. Rondenay, and D. H. Christensen (2006), Unusual mantle Poisson's ratio, subduction, and crustal structure in central Alaska, J. Geophys. Res., 111, B09311, doi:10.1029/2005JB003956.

Schutt, D. L., and C. E. Lesher (2006), Effects of melt depletion on the density and seismic velocity of garnet and spinel lherzolite, J. Geophys. Res., 111, B05401, doi:10.1029/2003JB002950.

Shinmei, T., N. Tomioka, K. Fujino, K. Kuroda, and T. Irifune (1999), In situ X-ray diffraction study of enstatite up to $12 \mathrm{GPa}$ and $1473 \mathrm{~K}$ and equations of state, Am. Mineral., 84(10), 1588-1594.

Skemer, P., I. Katayama, and S. Karato (2006), Deformation fabrics of the Cima di Gagnone peridotite massif, central Alps, Switzerland: Evidence of deformation at low temperatures in the presence of water, Contrib. Mineral. Petrol., 152(1), 43-51, doi:10.1007/s00410-006-0093-4.

Spandler, C., G. Yaxley, D. H. Green, and D. Scott (2010), Experimental phase and melting relations of metapelite in the upper mantle: Implications for the petrogenesis of intraplate magmas, Contrib. Mineral. Petrol. 160(4), 569-589, doi:10.1007/s00410-010-0494-2.

Speziale, S., T. S. Duff, and R. J. Angel (2004), Single-crystal elasticity of fayalite to $12 \mathrm{GPa}, J$. Geophys. Res., 109, B12202, doi:10.1029/ 2004JB003162.

Syracuse, E. M., G. A. Abers, K. Fischer, L. MacKenzie, C. Rychert, M. Protti, V. Gonzalez, and W. Strauch (2008), Seismic tomography and earthquake locations in the Nicaraguan and Costa Rican upper mantle, Geochem. Geophys. Geosyst., 9, Q07S08, doi:10.1029/2008GC001963.

Takei, Y. (2002), Effect of pore geometry on $V_{P} / V_{S}$ : From equilibrium geometry to crack, J. Geophys. Res., 107(B2), 2043 doi:10.1029/ 2001JB000522.

Thurber, C., and J. Ritsema (2007), Theory and observations-Seismic tomography and inverse methods, in Treatise on Geophysics, vol. 1, Seismology and the Structure of the Earth, edited by B. Romanowicz and A. Dziewonski, pp. 323-360, Elsevier, Amsterdam, doi:10.1016/B978044452748-6.00009-2.

Till, C. B., T. L. Grove, and A. C. Withers (2011), The beginnings of hydrous mantle wedge melting, Contrib. Mineral. Petrol., 163, 669-688.

Tsuji, Y., J. Nakajima, and A. Hasegawa (2008), Tomographic evidence for hydrated oceanic crust of the Pacific slab beneath northeastern Japan: Implications for water transportation in subduction zones, Geophys. Res. Lett., 35, L14308, doi:10.1029/2008GL034461.

Vauchez, A., F. Dineur, and R. L. Rudnick (2005), Microstructure, texture and seismic anisotropy of the lithospheric mantle above a mantle plume: Insights from the Labait volcano xenoliths (Tanzania), Earth Planet. Sci. Lett., 232, 295-314, doi:10.1016/j.epsl.2005.01.024.

Verma, R. K. (1960), Elasticity of some high-density crystals, J. Geophys. Res., 65(2), 757-766, doi:10.1029/JZ065i002p00757.

Wagner, L. S., S. Beck, and G. Zandt (2005), Upper mantle structure in the south central Chilean subduction zone $\left(30^{\circ}\right.$ to $\left.36^{\circ} \mathrm{S}\right)$, J. Geophys. Res., 110, B01308, doi:10.1029/2004JB003238.

Wagner, L. S., S. Beck, G. Zandt, and M. N. Ducea (2006), Depleted lithosphere, cold, trapped asthenosphere, and frozen melt puddles above the flat slab in central Chile and Argentina, Sci. Lett., 245, 289-301, doi:10.1016/j.epsl.2006.02.014

Wagner, L. S., M. L. Anderson, J. M. Jackson, S. Beck, and G. Zandt (2008), Seismic evidence for orthopyroxene enrichment in the continental lithosphere, Geology, 36, 935-938, doi:10.1130/G25108A.1.

Webb, S. L., and I. Jackson (1993), The pressure dependence of the elastic moduli of single-crystal orthopyroxene $\left(\mathrm{Mg}_{0.8} \mathrm{Fe}_{0_{2}} \mathrm{SiO}_{3}\right)$, Eur. J. Mineral., $5,1111-1119$

Wohlers, A., C. E. Manning, and A. B. Thompson (2011), Experimental investigation of the solubility of albite and jadeite in $\mathrm{H}_{2} \mathrm{O}$, with paragonite + quartz at 500 and $600^{\circ} \mathrm{C}$, and $1-2.25 \mathrm{GPa}$, Geochim. Cosmochim. Acta, 75, 2924-2939, doi:10.1016/j.gca.2011.02.028

Zhang, H., C. H. Thurber, D. Shelly, S. Ide, G. C. Beroza, and A. Hasegawa (2004), High-resolution subducting-slab structure beneath northern 
Honshu, Japan, revealed by double-difference tomography, Geology, 32 , 361-364, doi:10.1130/G20261.2.

Zhang, L., H. Ahsbahs, S. S. Hafner, and A. Kotoglu (1997), Single-crystal compression and crystal structure of clinopyroxene up to $10 \mathrm{GPa}$, Am. Mineral., 82, 245-258.

Zhao, D., Z. Wang, N. Umino, and A. Hasegawa (2009), Mapping the mantle wedge and interplate thrust zone of the northeast Japan arc, Tectonophysics, 467, 89-106, doi:10.1016/j.tecto.2008.12.017.
Zheng, Y., and T. Lay (2006), Low $V_{P} / V_{S}$ ratios in the crust and upper mantle beneath the Sea of Okhotsk inferred from teleseismic $p_{M} P, s_{M} P$, and $s_{M} S$ underside reflections from the Moho, J. Geophys. Res., 111, B01305, doi:10.1029/2005JB003724.

Zhu, L., and H. Kanamori (2000), Moho depth variation in Southern California from teleseismic receiver functions, J. Geophys. Res., 105, 2969-2980, doi:10.1029/1999JB900322. 